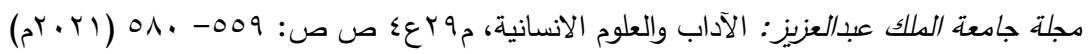

DOI:10.4197/Art.29-4.20

\title{
حسن التعامل بين الأزواج نماذج مضيئة في التاريخ من العصر النبوي حتى العصر العباسي
}

\author{
د. يوسف عبدالحميد بن ناجي \\ أستاذ مساعد في التاريخ الإسالامي- الهيئة العامة للتعليم التطبيقي بهي \\ و التدريب -كلية التربية الاساسية-قسم الدراسات الاجتماعية \\ دولة الكوبت -العارضيت- قطعة ا - شارع محدم ابن القاسم-مقابل أستاذ جابر
}

مستخلص. هذه الدراسة تبحث عن المعاملة الحسنة بين من حكما الدولة الإسلامية وزوجاتهم منذ عصر النبي صلى الله عليه وسلم وحتى العصر العباسي، وقد ذكرت نماذج من التاريخ لكل عصر من العصور الإسلامية منها نماذج عن النبي وزوجته عائشة رضي الله عنها، عثمان بن عفان رضي الله عنه وزوجته نائلة، عمر بن العزيز وزوجته

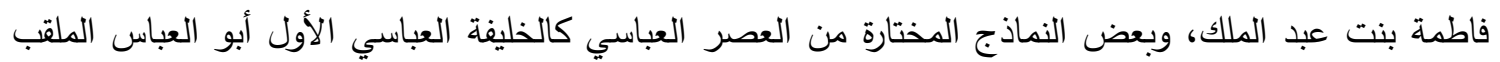
بالسفاح وزوجته أم سلمة بنت يعقوب بن سلمة، وأبو جعفر المنصور وزوجته أروى القيروانية، والخليفة المهدي

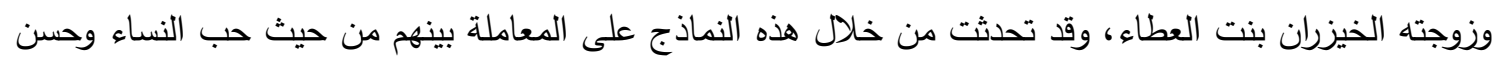
الخلق معهن، ملاطفة النساء، التضحية والوفاء، العيش الزهيد، المشورة، وكان منهجي في هذا البحث هو المنهج الوصفي التحليلي القائم على ذكر نماذج من حسن المعاملة بين الأزواج وخاصة الذين قادوا الأمة الإسلامية من عصر النبوة وحتى العصر العباسي وذلك من خلال ما ورد في بعض المصادر والمراجع وتحليلها والتعليق عليها قدر الاستطاعة، وقد استخلصت من هذا البحث بعض النتائج منها: أن المعاملة بين الأزواج خلال عصر فئر النبوة والخلافة الراشدة كانت قائمة على حسن الخلق والمحبة والملاطفة والتضحية والوفاء وغيرها من الصفات الحسنة دون التخخل في أمور السياسية، مما كان له أعظم الأثر من نشر المحبة والألفة بين أفراد الأسرة الواحدة بل بين أفراد

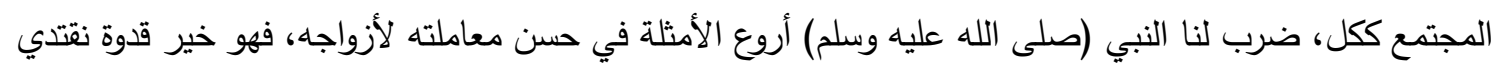
باه، في أعماله، وأقواله، وأخلاقه، وكلِّ جزئيات سلوكه في الحياة، ولا يخلو عصر من العصور من وجود طائفة من

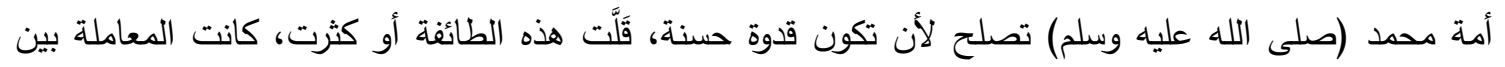




$$
\text { يوسف عبدالحميد بن ناجي }
$$

الخلفاء وزوجاتهم في العصر العباسي تحول إلى عشق للنساء مما جعل النساء صرن يتحكمن في أمور الدولة مما

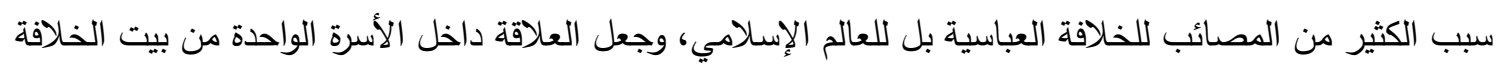

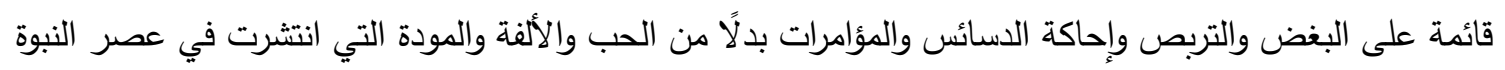

$$
\text { - (نماذج مختارة من العصر العباسي). }
$$

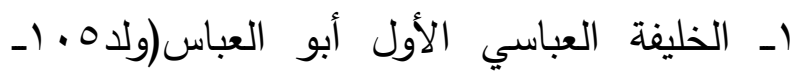

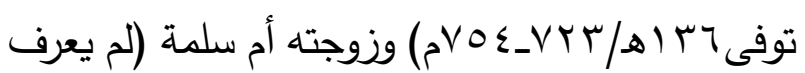
لا لها تاريخ ولادة أو وفاة).

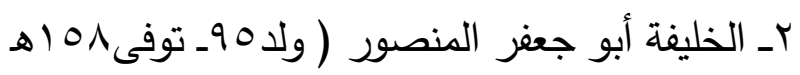

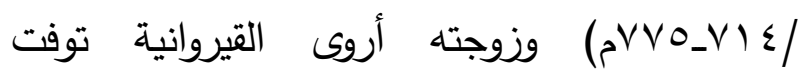

$$
\text { . }(5 V T / 4)
$$

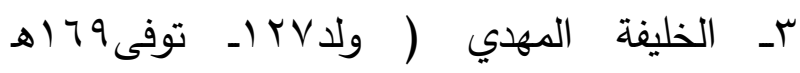

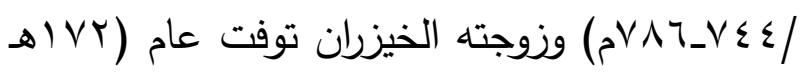
$\cdot(a \vee \wedge \Lambda)$

$$
\text { أما عن منهج البحث: }
$$

فقد اعتمدت المنهج الوصفي التحليلي القائم على ذكر

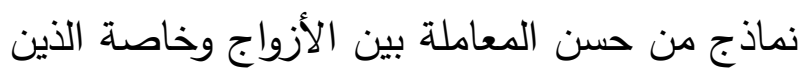

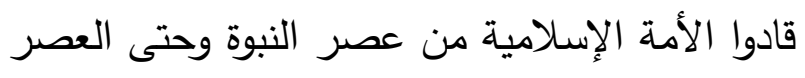

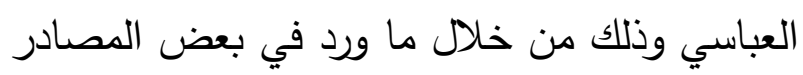

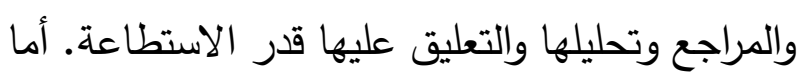
عن الدراسات السابقة: فعلى حد علمي ليس هنالك دراسات تتعلق بهذا الموضوع سوى في عصر النبوة

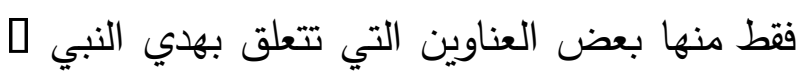

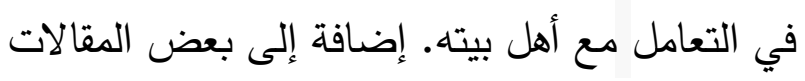

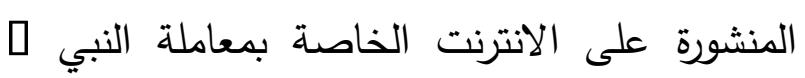

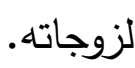
والخلافة الراشدة.

\section{المقدمة}

الحمد لله رب العالمين والصلاة والسلام على المبعوث رحمة للعالمين سيدنا محمد، وعلى آله وصحبه، ومن سار على نهجه إلى يوم الدين، وبعد ...

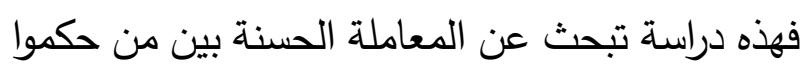

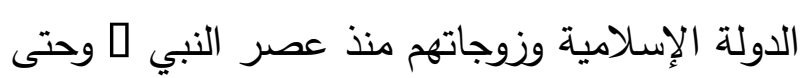

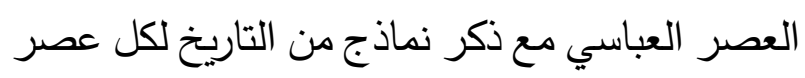
من العصور ، وسوف تشمل خطة البحث النقاط الآتية. 1 ـ حب النساء وحسن الخلق معهن. r- ملاطفة النساء. rـ التضحية والوفاء. عـ العيش الزهيد. 0ـ المشورة. مع ذكر نماذج مختارة لكل عنصر من هذه العناصر وتتمثل هذه النماذج في الآتي:

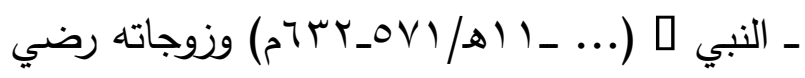
الله عنهن.

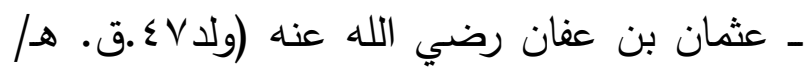

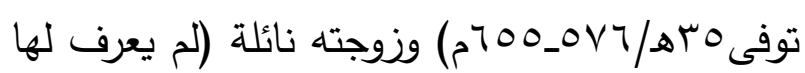
تاريخ ولادة أو وفاة).

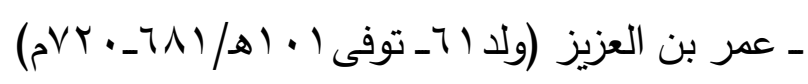
وزوجته فاطمة بنت عبد الملك(توفت عام هـ ـ اوقيل

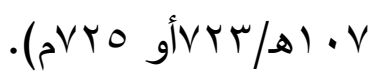




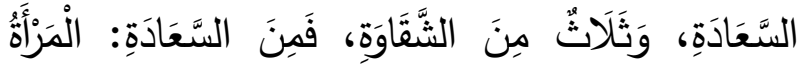

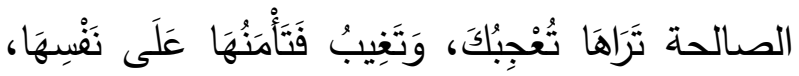

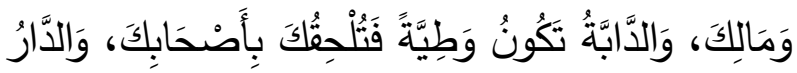

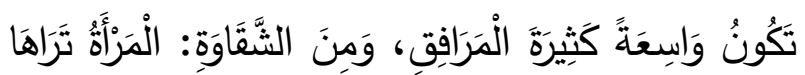

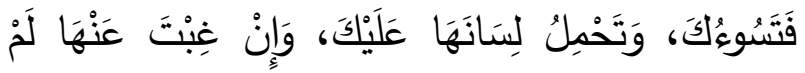

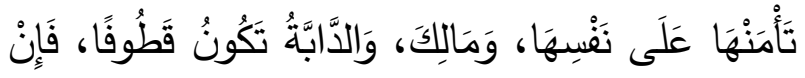

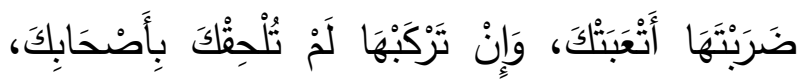

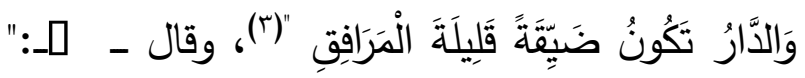

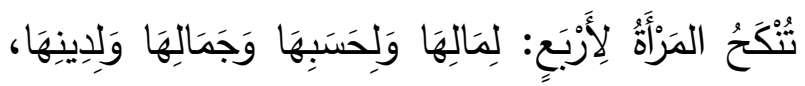

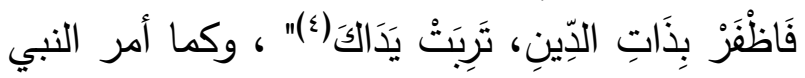

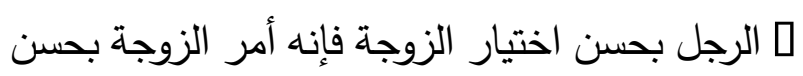

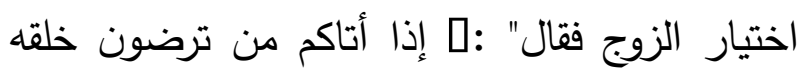
ودينه فزوجوه، إلا تفعلوا تكن فتتة في الأرض وفساد عريض.(0)" والرجل الصالح مع المرأة الصالحة يبنيان بيتًا صالحًا،

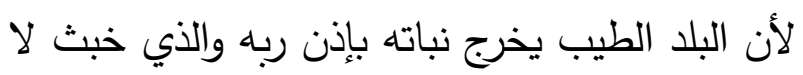
يخرج إلا نكدا، وبطبيعة الحال يكون هذا البيت قائم على الطاعة لله سبحانه وتعالى ولرسوله الكريم 1 كما تكون العلاقة بين الزوجين قائمة على حسن المعاملة حب الرجل لزوجته والعكس وحسن الخلق بينه

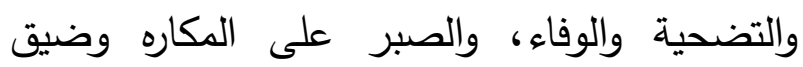

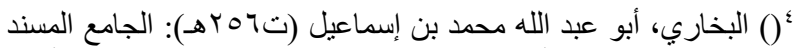

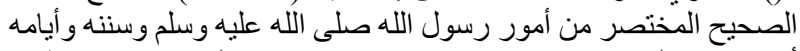

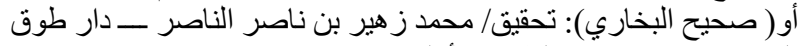

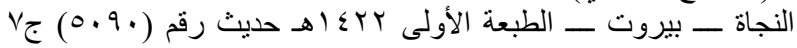

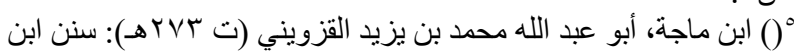

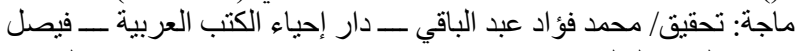

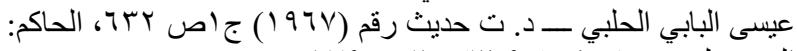

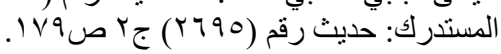

أما عن العصور الأخرى فلم يصادفني أي عمل متخصص في هذا الموضوع. تمهيا

جعل الله سبحانه وتعالى العلاقة الزوجية في الثريعة الإسلامية قائمة على المودة والعطف والسَّكَينّة والرحمة بين كِلا الزوجين ليسكن كل منهما للآخر ولتتوطدا

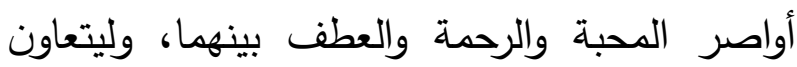
الزوجان في الحياة الزوجية فيما يُرضي الله تعالى ولى ولئه

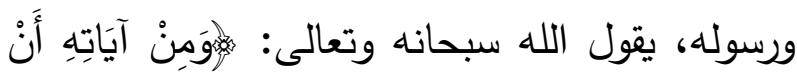

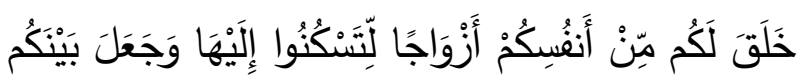

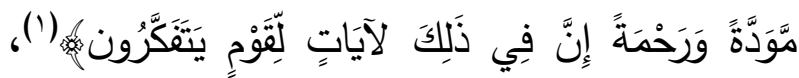

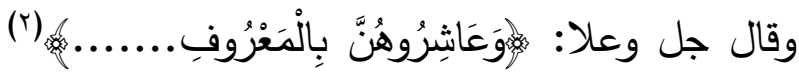
بالكلام الطيب، بالأسلوب الحسن، بالحلم، بالخلق

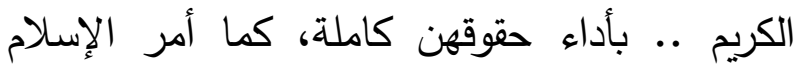

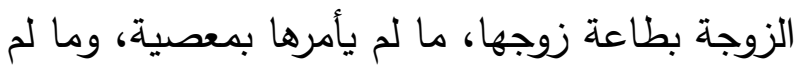

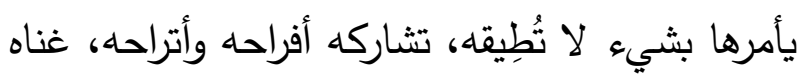

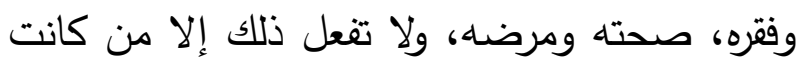
صالحة، والمرأة الصالحة تكون من أسباب السعادة، وصنه

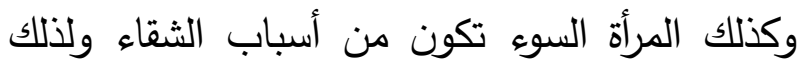

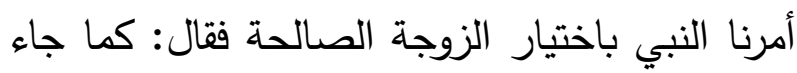

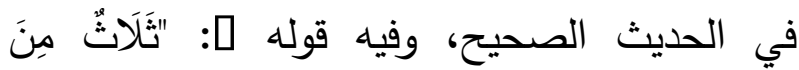

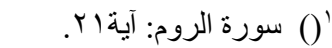

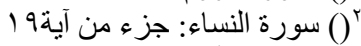

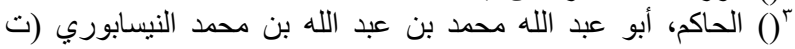

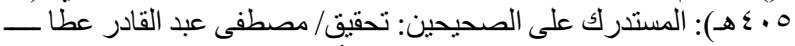

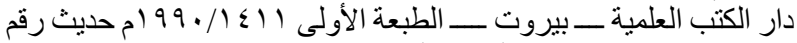

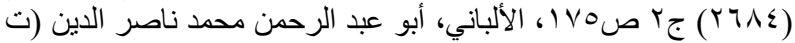

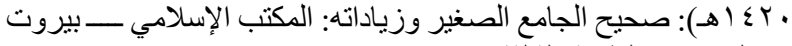

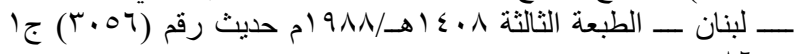


فكان اليهود إذا حاضت المرأة لم يؤاكلوها ولم يشاربوها. وجاءت النصرانية فقال النصارى: إن المرأة مخلوق نجس لا يحق لها أن تمس الكتاب المقدس، ولفاءل

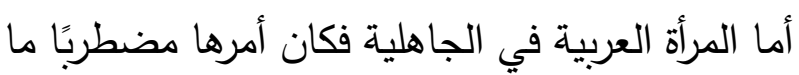
بين تتصيبها ملكة (كبلقيس) في عهد نبي الله سليمان ـ عليه السلام -، وبين وأدها حية، أو ميراثها كرهًا عنها، وحرمانها من ميراث والديها وأولادها، وإكراها على الزواج ممن ترضى ومن لم ترض.... ولما جاء

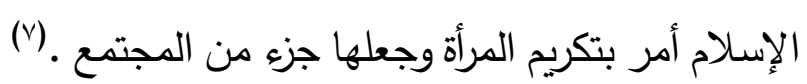
ولنا في رسول الله (صلى الله عليه وسلم) الأسوة

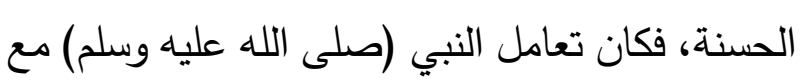
زوجاته تعامل لين ورحمة ومحبة، فلقد كان الرسول (صلى الله عليه وسلم) أكثر الناس حبًا لزوجاته، وكان

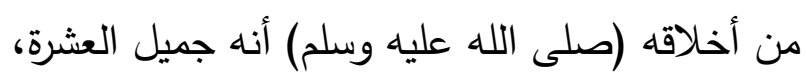
دائم البشر، يداعب أهله، ويتلطف بهم، ويضاحك عله نساءه، وهذا ما سنعرفه ويتبين لنا، وذلك من خلال متابعتا لهذه النماذج الحية من حياته (صلى الله عليه وسلم): فعن أنس بن مالك 0 قال :" خرجنا الى المدينة

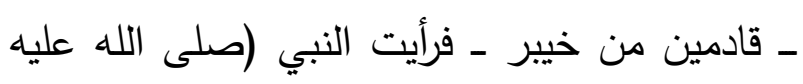

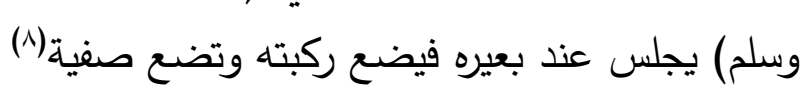

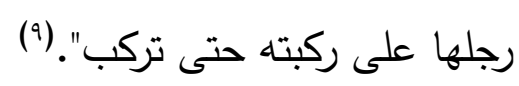

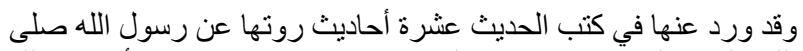

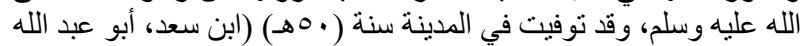

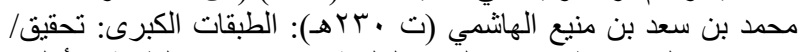

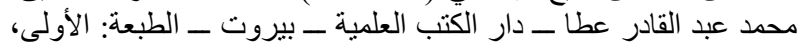

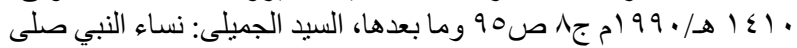

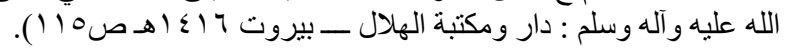

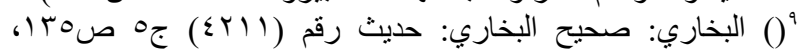

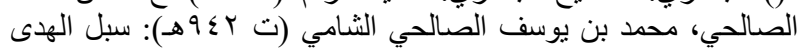

العيش، والمشورة، واحترام كل منهما للآخر ، والتاريخ الإسلامي مليء بمثل هذه النماذج، وسوف أقتصر على بعض العناصر الآتية مع ذكر نماذج لها من لهن لهن التاريخ:

\section{المبحث الأول}

حسن التعامل بين الأزواج نماذج من عصر النبوة والخلافة الراشدة

1 ـ حب النساء وحسن الخلق معهن.

لا شك أن النساء شقائق الرجال، وبينهما روابط تكوينية من أول وجودهما، وقد أشار القرآن الكريم

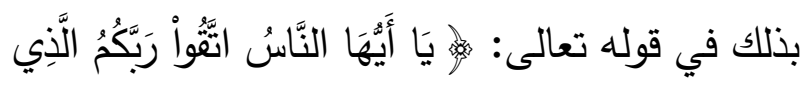

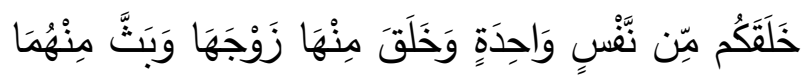

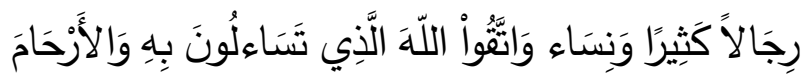

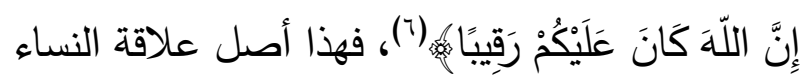
بالرجال، أن الجميع من أصل واحد هو آدم وزوجه

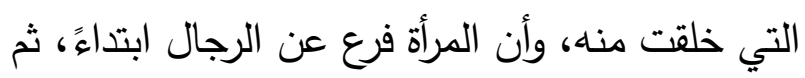
تناسل الأصل وتكاثر الفرع حتى تواجدت الأمم

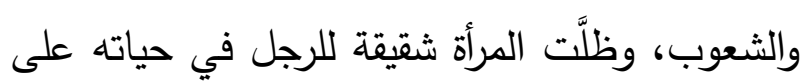
مدى العصور، حتى لعبت بها الأهواء، وتقاذفتها الأغراض، واختلفت وجهات النظر فيها، وأصبحت

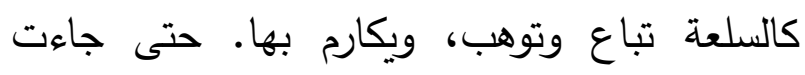

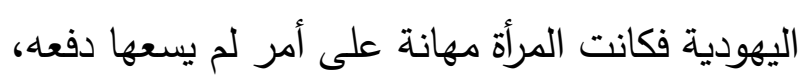

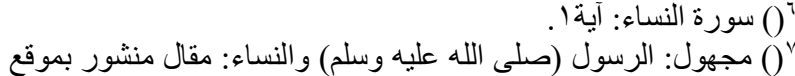
الكلم الطيب. (الرسول

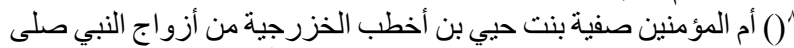

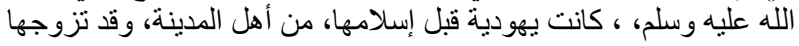

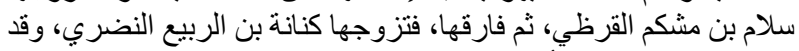

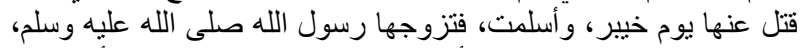

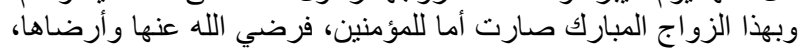


أما عن مواقف حبه (صلى الله عليه وسلم) لعائشة رضي الله عنها فكثيرة منها: ما روته عائشة رضي روني الله عنها حيث قالت: كان رسول الله صلى الله عليه

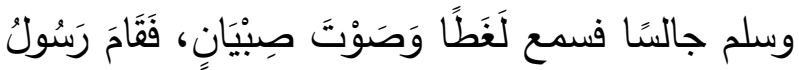

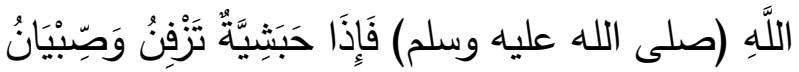

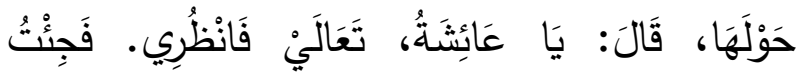

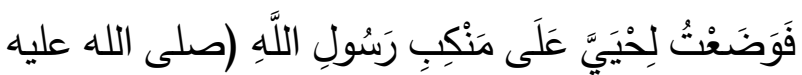

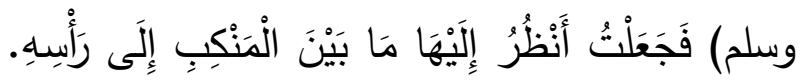

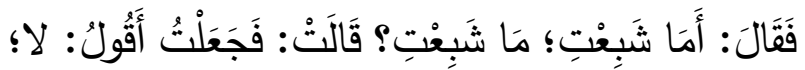

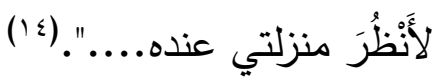
أما عن حسن خلقه (صلى الله عليه وسلم) معها فقد متردي

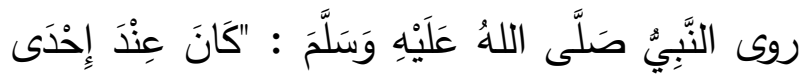

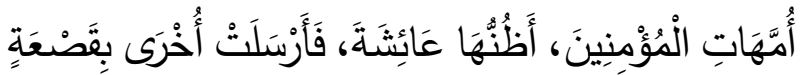

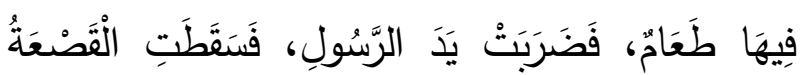

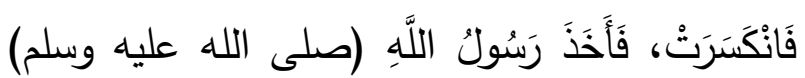

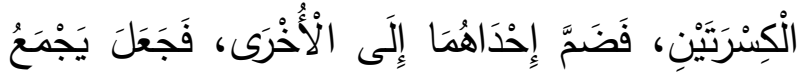

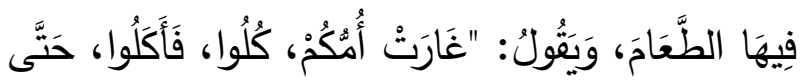

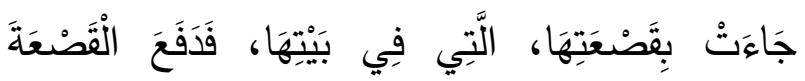

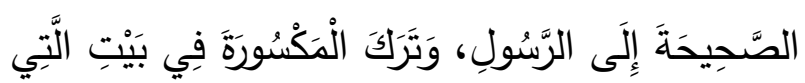

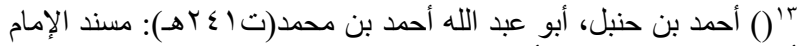

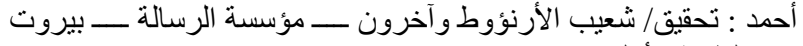

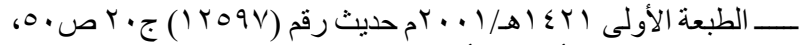

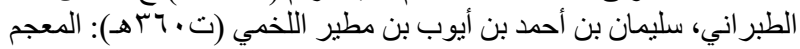

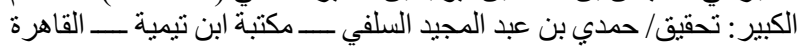

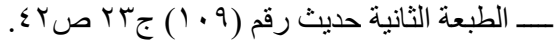

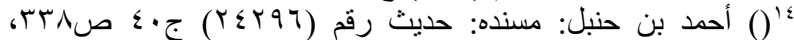

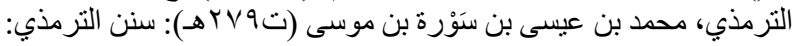

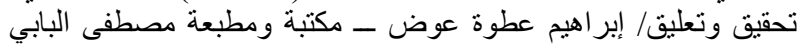

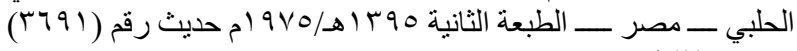

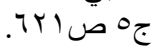

فهذا الموقف وإن رآه البعض بسيطًا أو عاديًا، لكنه يخبرنا عن حب النبي (صلى الله عليه وسلم) لصفية لصنية ـ رضي الله عنها ـ فلم يخجل (صلى الله عليه وسلم) من أن يرى أصحابه هذا المشهد وهو يظهر الحب

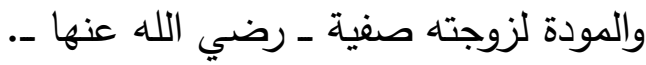

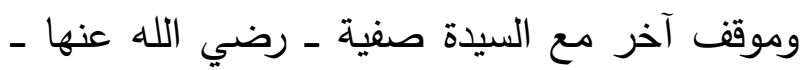

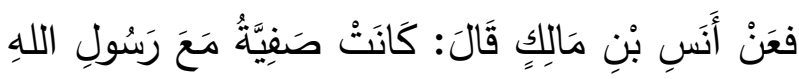
(صلى الله عليه وسلم) فِي سَفَرِ، وَكَانَ ذَلْلَكَ يَوْمَهَا

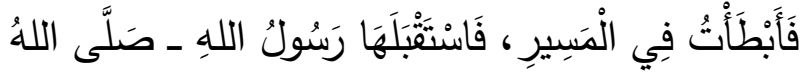

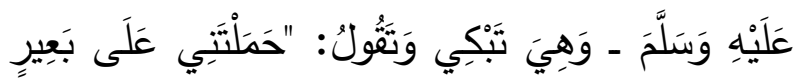

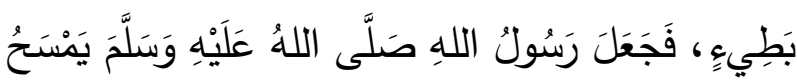

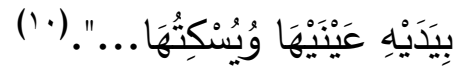
أما عن حب النبي (صلى الله عليه وسلم) لعائشة ـ ـائل رضي الله عنها ـ فحدث ولا حرج، فقد كانت أحب أب أبه النساء إليه وقد روي أنه (صلى الله عليه وسلم) سئل:

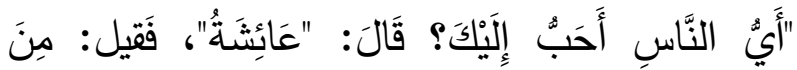

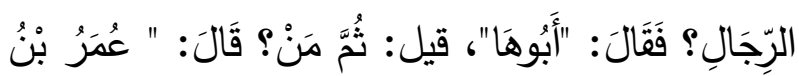

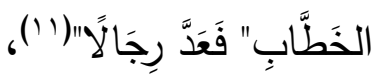

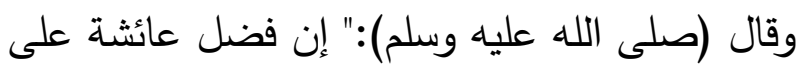

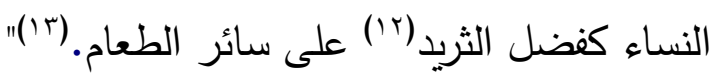

والرشاد، في سيرة خير العباد، وذكر فضائله وأعلام نبوته و أفعاله وأحو اله اله

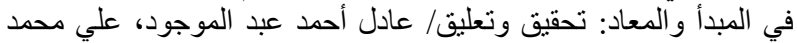

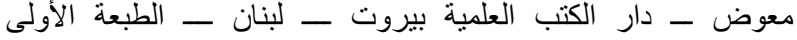

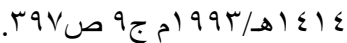

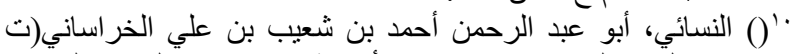

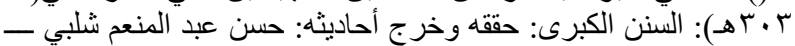

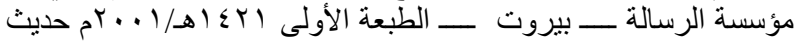

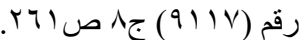

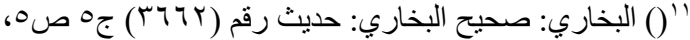

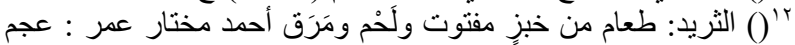

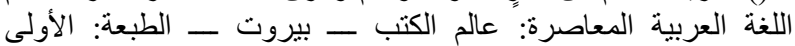
每 
وَنَبِيتُ خَرَجْتُ مَعَهُ فِي بَعْضِ أَسْفَارِهِ فَفَالَ لِلنَّاسِِ

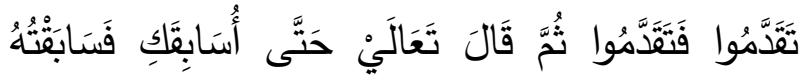

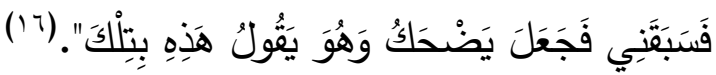
وكان من هديه (صلى الله عليه وسلم) محادثة نسائه ومؤانستهن ففي سنن أبي داود عن عائشة رضي الله

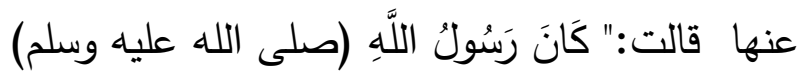

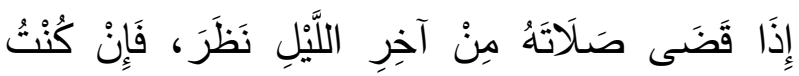

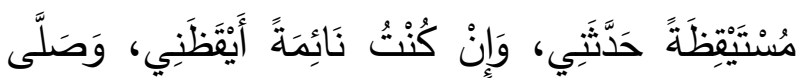

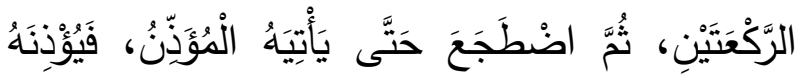

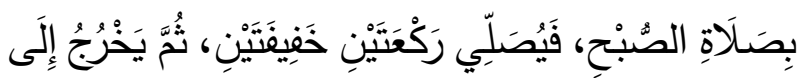

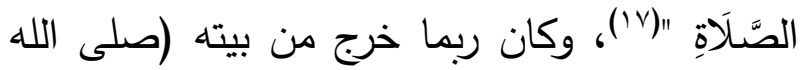
عليه وسلم) إلى الصلاة فيقبل إحداهن، وحث أصحابه

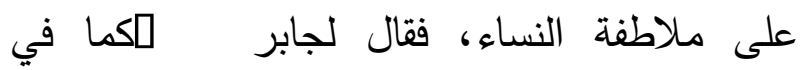

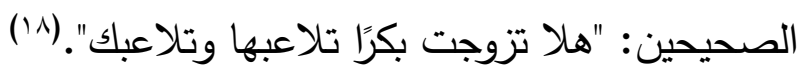
وعن عائشة رضي الله عنها قالت: "كَانَ رَسُولُ اللَّهِ

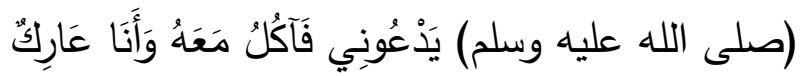

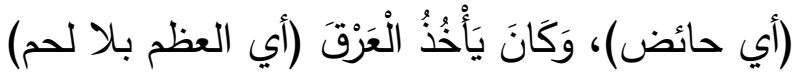

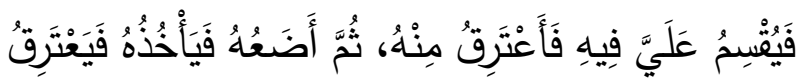

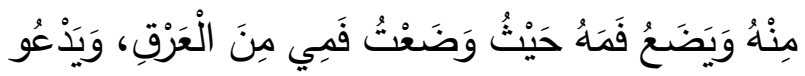

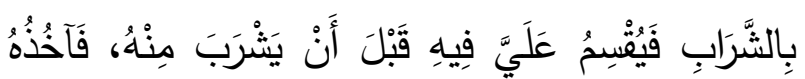

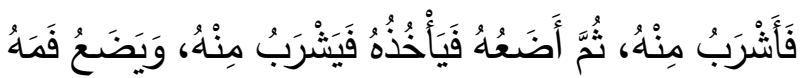
حَيْنُ وَضَعْتُ فَمِي مِنَ الْقَدَحِ".

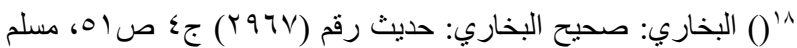

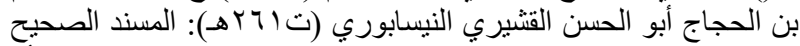

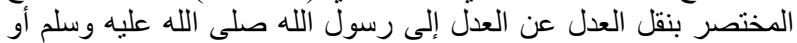

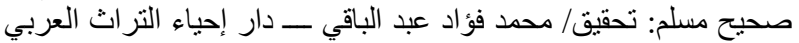

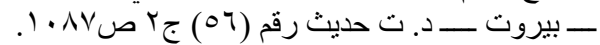

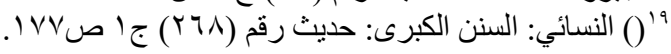

كَسَرَتْهَا" .(10)أي أنه صلى الله عليه وسلم أَعطى الصَّحفِة الصحيحةِ لزوجته الأخرى وترك المكسورة في

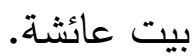
هذا الموقف وغيره يدل على حسن خلق النبي صلى الله عليه وسلم مع زوجاته، وأقول لو حدث مثل هذا الموقف وربما أقل منه مع رجل في زمننا هذا أمام أصحابه فهل سيكون في موقفه متأسيًا برسول الله

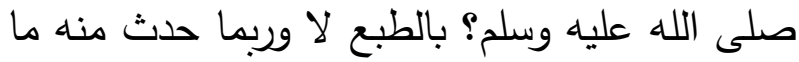
لا يحمد عقباه، ولا أجزم بأي عقاب، فلكل رجل طبيعته الخاصة، فهناك من يضرب، وهناك من يكون موقفه إنهاء العلاقة، وربما يكون هنالك أسوأ من ذلك. r- ملاطفة النساء وملاعبتهم. لنا في رسول الله (صلى الله عليه وسلم) في ملاطفة نسائه وملاعبتهم الأسوة حسنة، فقد كان جميل

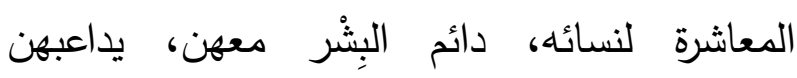
ويلاطفهن ويضاحكهن، حتى إنه كان يسابق عائشة ويتودد إليها بذلك، تروي السيدة عائشة رضي الله عنها كيف سابقها النبي (صلى الله عليه وسلم) فقَالَتْ:

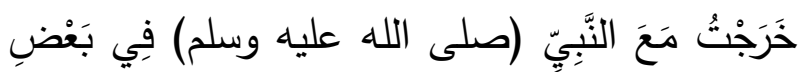

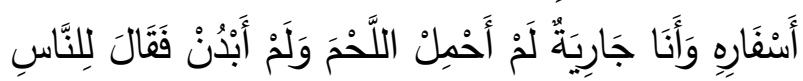

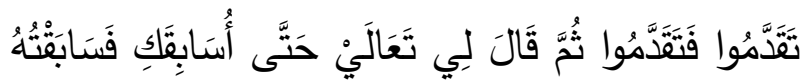

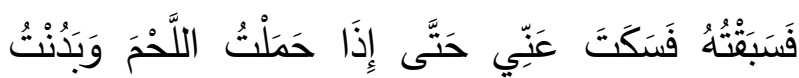

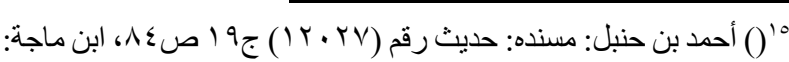

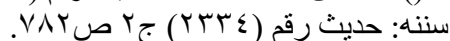

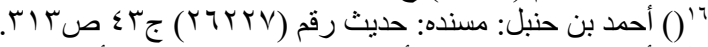

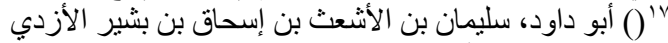

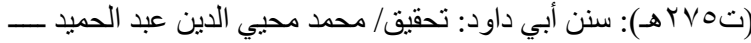

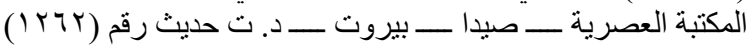

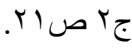




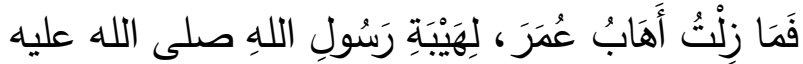
وعن النعمان بن بشير - رضي الله عنه ـ قال: استأذن أبو بكر - رضي الله عنه على النبي - صلى الله عليه وسلم ـ فسمع صوت عائشة رضي الله عنها عاليًا، فلما دخل تتاولها ليلطمها، وقال: لا أراك ترفعين صوتك على رسول الله (صلى الله عليه وسلم)! فجعل النبي ـ صلى الله عليه وسلم - يحجزه، وخرج أبو بكر مغضبًا، فقال النبي ـ صلى الله عليه وسلم - - حين خرج أبو بكر :"كيف رأيتيني أنقذتك من الرجل!"، قال: فمكث أبو بكر أيامًا، ثم استأذن، فوجدهما قد اصطلحا، فقال لهما: أدخلاني في سلمكما كما أدخلتماني في حربكما! فقال رسول الله (صلى الله عليه وسلم): "قد فعلنا، قد فعلنا" . (ro() هذه النماذج وغيرها الكثير تبين لنا حسن تعامل النبي (صلى الله عليه وسلم) مع زوجاته، وهذا الهدي النبوي قدوة لكل زوجين ينغمسان في مشاغل الحياة وهمومها وينسيان أن مداعبة أحدهما للآخر وملاطفته وتمضية

محمد (المتوفى: ؟ ـ آهـ): النهاية في غريب الحديث والأثر تحقيق: طاهر

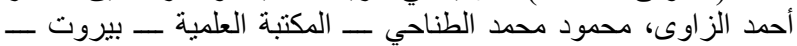
(

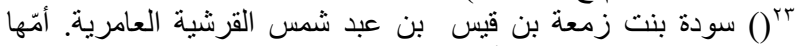

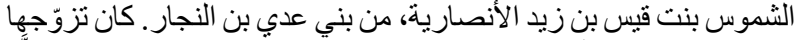

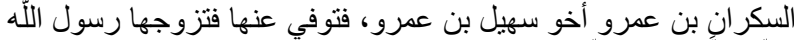

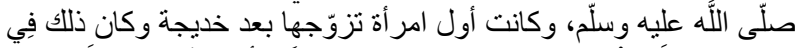

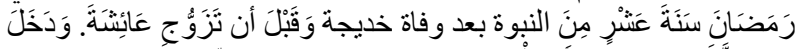

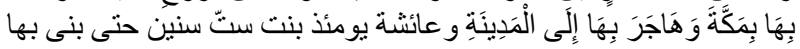

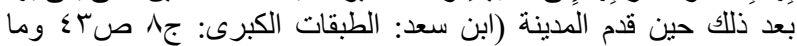
بعدها). (1) بعان.

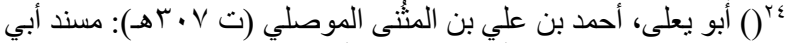

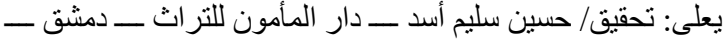

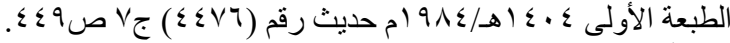

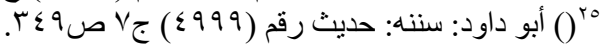

وقد روي أن زَنْنَبُ (r) كَانَتْ تَقْلِي رَأْسَ رَسُولِ اللَّهِ (صلى الله عليه وسلم)، وَعَنْدَهُا بعض النساء مِنَ

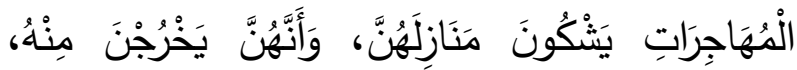

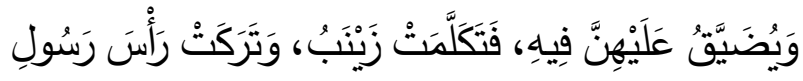
اللَّهِهِ (صلى الله عليه وسلم)، فَقَالَ رَسُولُ اللَّهِ صَلَّى

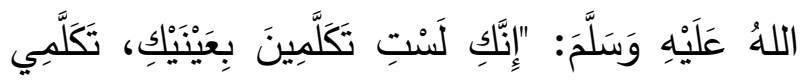
وَاعْمَلِي عَمَلَكِ". وعن عائشة رضي الله عنها قالت : أَتَيْتُ النَّبَّيَّ صلى

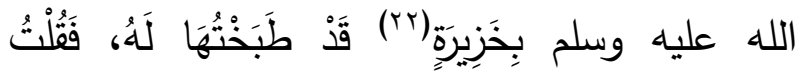

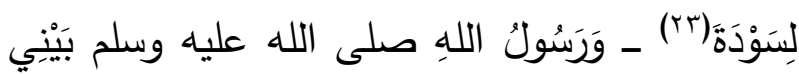

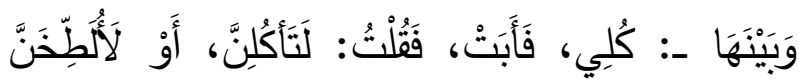

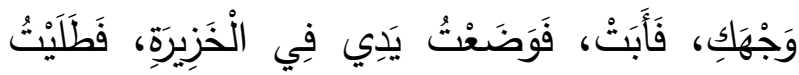
وَجْهَهَها، فَضَحِكَ رَسُولُ اللهِهِ صلى الله عليه وسلم، فَوَضَحَ بِيَدِهِ لَهَا وَقَالَ لَهَا: ألُْطَنِي وَجْهَهَا، فَضَحِكَ رَسُولُ الللهِ صلى الله عليه وسلم لَهَا، فَمَرَّ عُمَرُ بن الخطاب رضي الله عنه فَقَالَ: يَا عَبْدَ اللهِ، يَا عَبْدَ

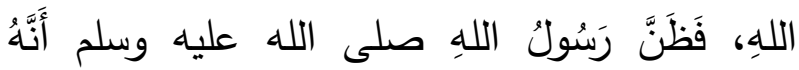
سَيَكْخُلُ، فَقَالَ: قُومَا فَاغْسِلَ وُجُوهَكُمَا، قَالَتْ عَائشََْةُ:

والبة) زينب بنت جحش بن رئاب الأسدية، من أسد خزيمة، أم المؤمنين،

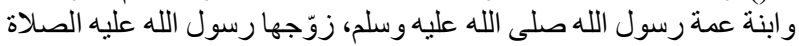

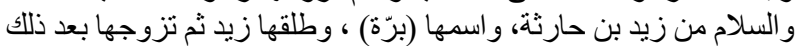

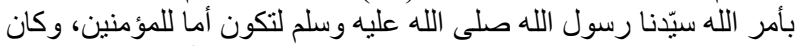

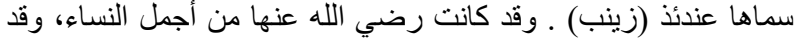

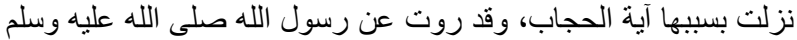

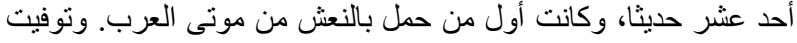

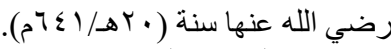

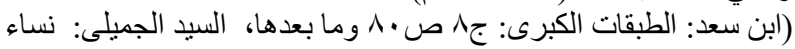

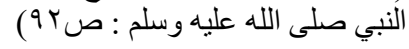

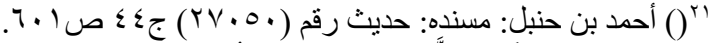

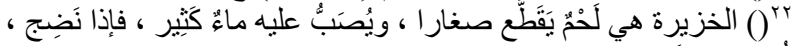

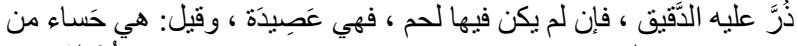

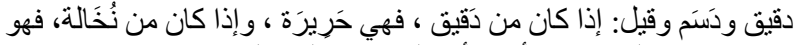

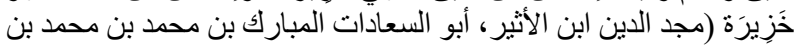


منه منحة من الله وفضل منه، حتى لا تتقطع صلته ببيت النبوة، لكنها ماتت هي الأخرى عام

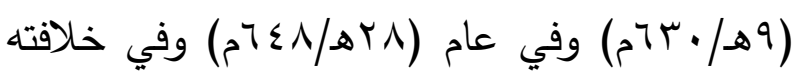

تزوج عثمان بنائلة بنت الغرافصة. (rV) أحب عثمان نائلة حبًا شديدًا، ومما يروى عنهما أنه خاف أن تكره فيه صلعته يوم الزفاف، فقال مداعبًا لها

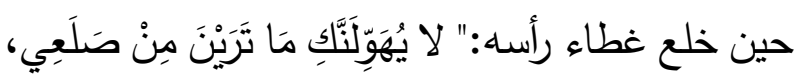

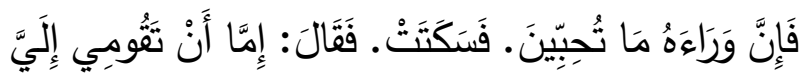

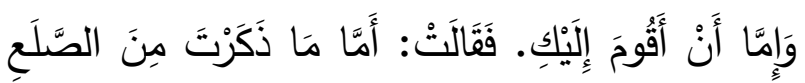

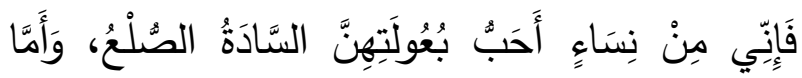
قَوْلُكَكَ: إِنْ تَقُومِي أَوْ أقوم، فِو الله لِمَا تَجَشَّمْتُ مِنْ

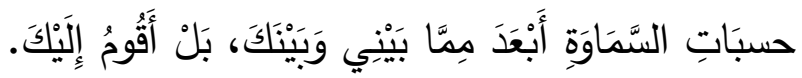

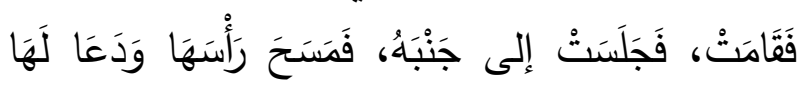

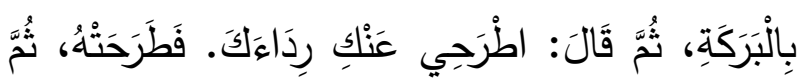

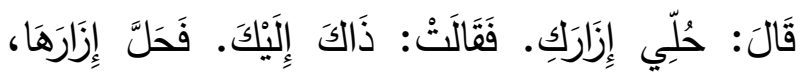

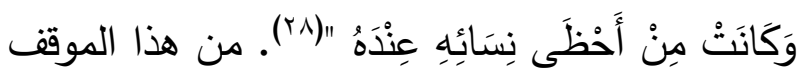
يتبين لنا مدى حرص عثمان - رضي الله عنه ــ على حسن معاملته لزوجته ومداعبته لها. rـ التضحية والوفاء.

إذا انتقلنا إلى التضحية والوفاء بين الأزواج، فلنا في رسول الله (صلى الله عليه وسلم) وزوجاته الأسوة

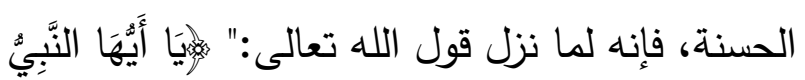

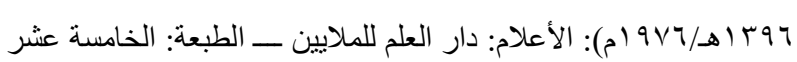

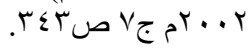

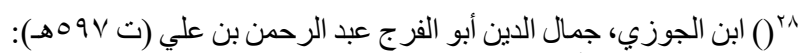

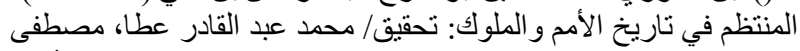

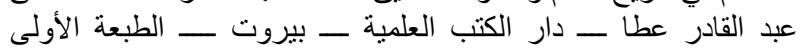

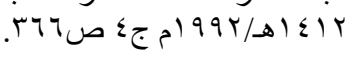

بعض الوقت معه في أحاديث جانبية تزيد من قوة ذلك الرباط المقدس الذي بينهما، وترفع من وتيرة الحب

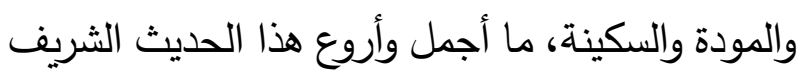
الذي يقول فيه النبي (صلى الله عليه وسلم):" كُلٌّ

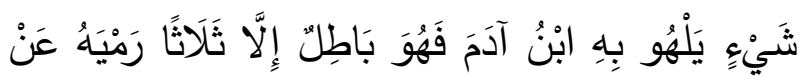

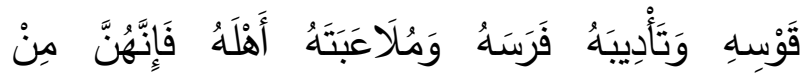

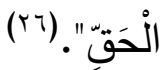
وبعد ذكر هذه النماذج من حياة النبي (صلى الله عليه وسلم) ومعاملته الحسنة مع زوجاته، أنتقل إلى خليفة من الخلفاء الراشدين لأذكر نموذجًا من حياته في معاملته مع زوجاته، وهو عثمان بن عفان - رضي الله عنه ـ الذي تزوج بابنتي رسول الله (صلى الله عليه وسلم). ففي البداية تزوج بالسيدة رقية فكانت نعم الزوجة لزوجها وكان عثمان نعم الزوج لزوجته، ولما مرضت لدرجة أنها كانت لا تستطيع القيام لازمها زوجها الحنون يُمرِضها، ويقوم برعايتها، واستمر عثمان زوجها الوفي إلى جانبها يرعاها ويخدمها حتى انتقلت إلى الرفيق، وبعد وفاتها تزوج بأختها أم كلثوم، وكان عثمان بن عفان - رضي الله عنه ــ ذا قلب رحيم وخلق دمث، فأحسن معاشرتها وظل يقدرها، خاصة أنها لم تتجب له طيلة فترة زواجها به وحتى توفاها الله فى بيته، لكنه كان يحبها ويعتبر زواجها

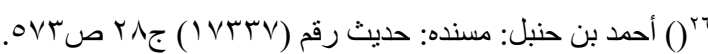

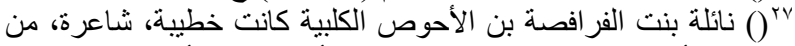

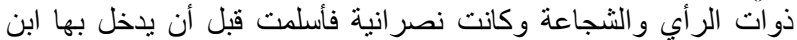

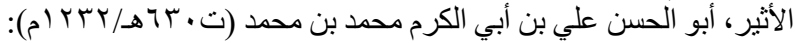

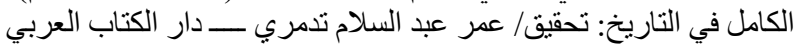

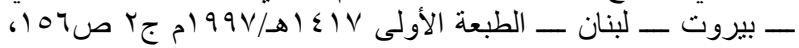

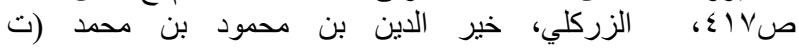


ومثال آخر للتضحية والوفاء تضربه لنا السيدة نائلة زوجة الخليفة عثمان بن عفان رضي الله عنه فإنه لما حوصر بيت الخليفة عثمان رضي الله عنه يريدون قتله في زمن الفتنة، ولما دخلوا إلى الدار حاولت

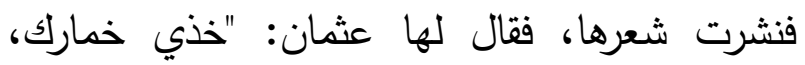
فلعمري لاخولهم علي أعظم من حرمة شعرك"، لكن

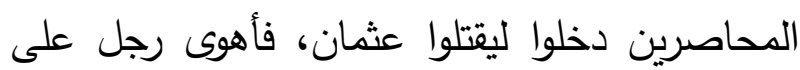
عثمان بالسيف، فانكبت عليه واتقت السيف بيدها لهانها

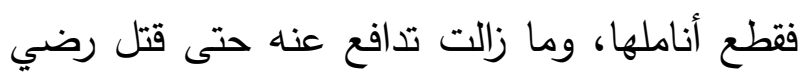

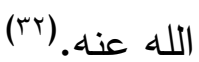
فأي زوجة هذه التي تضحي بحياتها فداء لزوجها، وأي زوج هذا الذي يفضل دخول المتمردين عليه وقتله بدلًا لـأل من أن يرى أحد شعر زوجته، إنه الخليفة الراشد عثمان بن عفان رضي الله عنه الذي تستحي منه الملائكة كما أخبرنا النبي (صلى الله عليه وسلم).

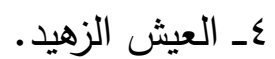
إن زوجات النبي (صلى الله عليه وسلم) عشن معه الرهيد حياة طيبة كريمة، حياة الزوج الرؤوف الرحيم ذي الأخلاق العظيمة والصفات الجليلة حياة بسيطة خالية من أي مظاهر الترف، فلم تكن عائشة تعيش في قصر ، ولكنها كانت حجرة صغيرة غرب المسجد، نحو لهون ست أو سبع أذرع، جدارها من طين، وسقفها من جريد

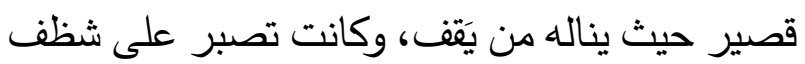

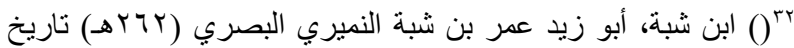

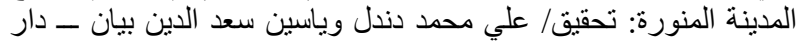

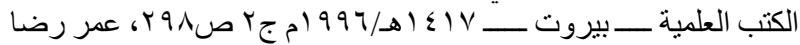

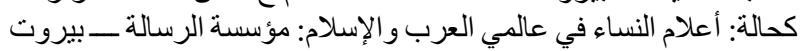

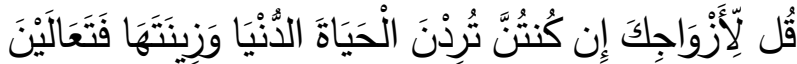

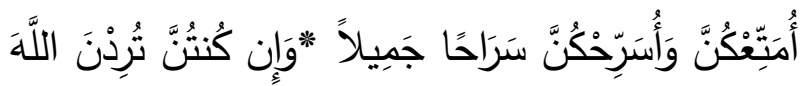

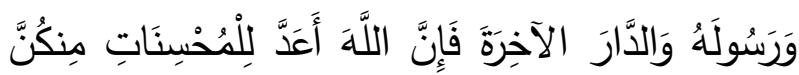

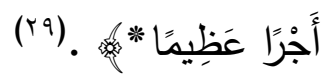
بدأ النبي (صلى الله عليه وسلم) بعائشة - رضي الله

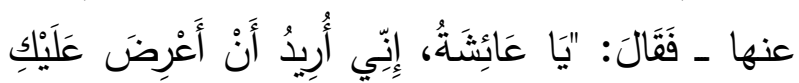

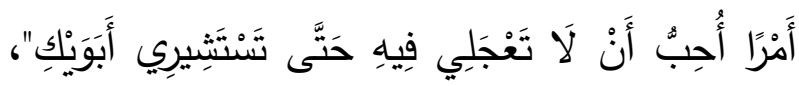

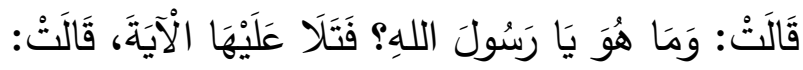

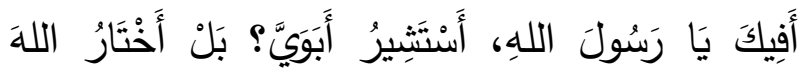

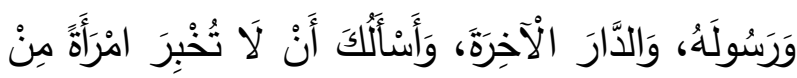

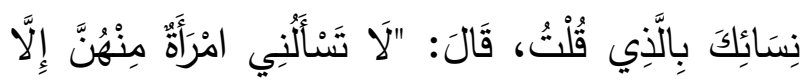

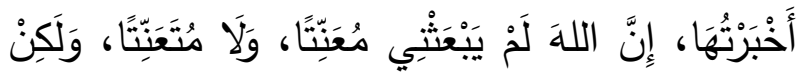

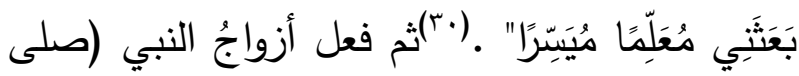

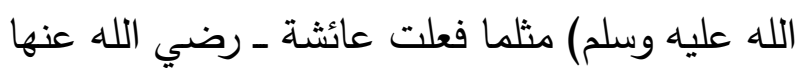
(r). وهكذا تختار أم المؤمنين عائشة - رضي الله عنها -

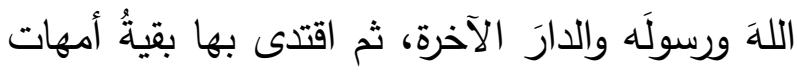

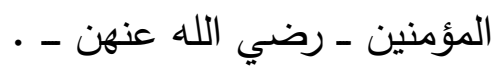

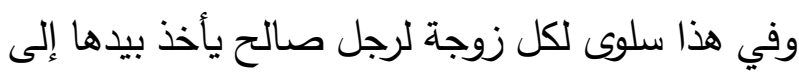

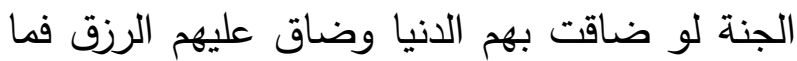

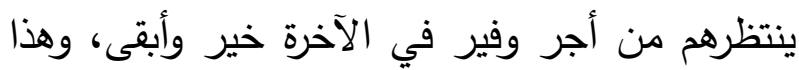

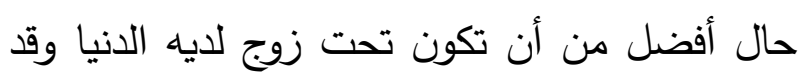

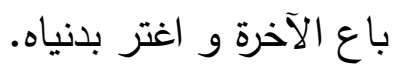

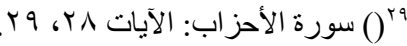

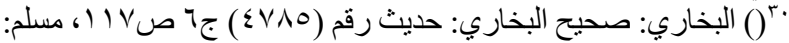

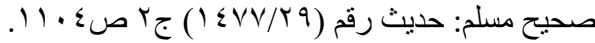

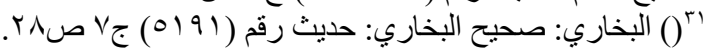


فإذا قام بسطتهما"، قالت: "والبيوت يومئذ ليس فيها

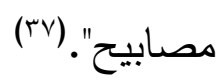

وقُبض رسول الله (صلى الله عليه وسلم) وما في بيته طعام، فعن عائشة ـ رضي الله عنها ـ قالت : توفي رسول الله (صلى الله عليه وسلم) وَمَا فِي بَيْتِي مِنْ

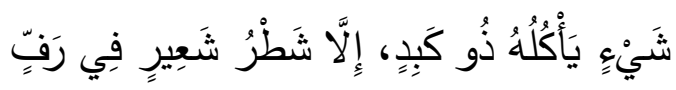

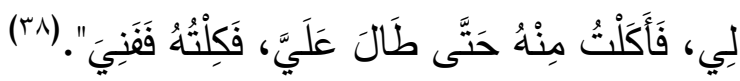
○ـ المشورة. لقد كان النبي (صلى الله عليه وسلم) يأخذ برأي زوجاته في بعض الأمور، ومن ذلك ما رواه البخاري:

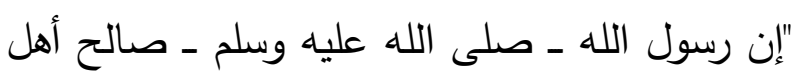
مكة، وكتب كتاب الصلح بينه وبينهه، فلما فرغ قال للناس: "قوموا فانحروا، ثم احلقوا". قالا: فوالله ما قام

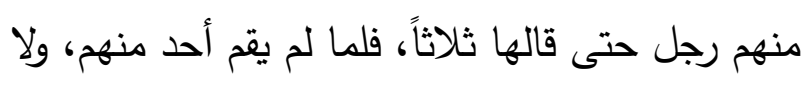

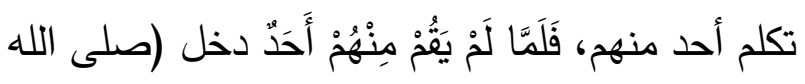

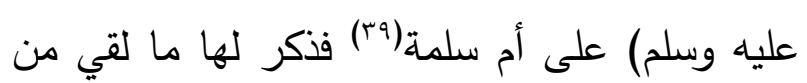

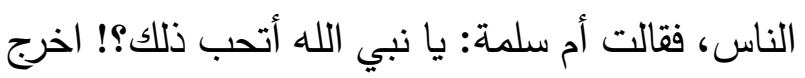

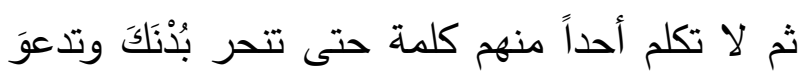
حالقك فيحلقك. فخرج ففعل ذلك، فما رأوا ذلك قاموا

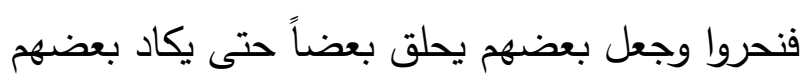

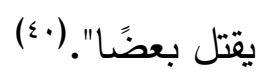

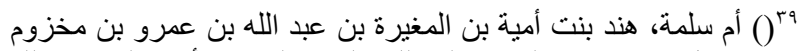

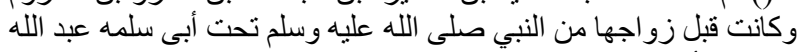

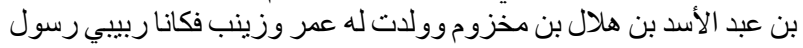

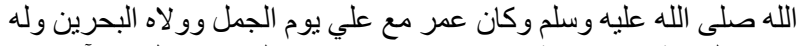

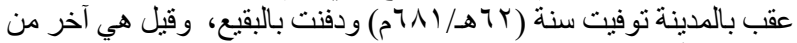
توفى من أزواج النبي صلى الله عليه وسلم (ابن سعد: الطبقات الكبرى:

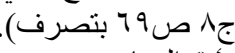

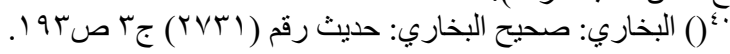

العيش فتحكي عن حياتها اليومية، فتقول: "ما شبع آل محمد (صلى الله عليه وسلم) من خبز بُر مأدوم (أي:

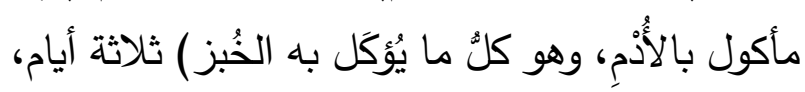
حتى لحق بالله عز وجل"( مَّ). وفي رواية أنها سُئلت : ما كان يعيشكم؟ قالت: الأسودان التمر والماء، إِلَّ أَنَّنُ

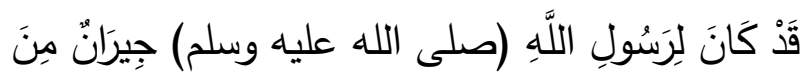

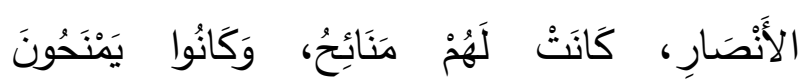

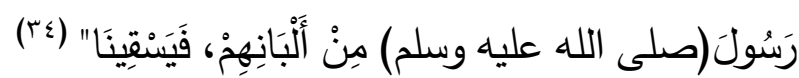

وروي عن عائشة ـ رضي الله عنها ـ قالت : "لقد كان فراش رسول الله (صلى الله عليه وسلم) الذي ينام عليه أدمًا، حشؤه ليف".(ro)

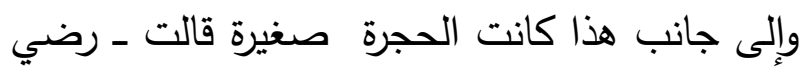
الله عنها ـ-: "والله، لقد رأيتُ رسول الله (صلى الله عليه وسلم) يصلي، وإني على السرير بينه وبين القبلة،

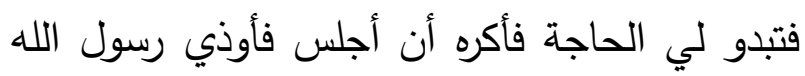

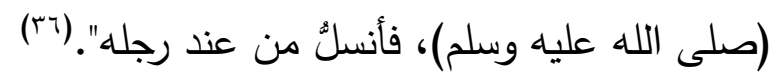

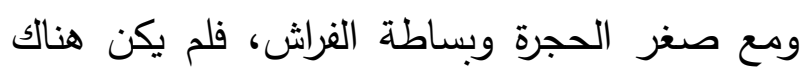

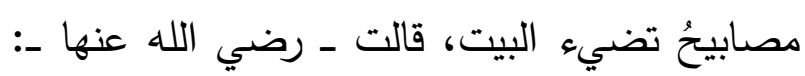
"كنت أنام بين يدي رسول الله (صلى الله عليه وسلم)،

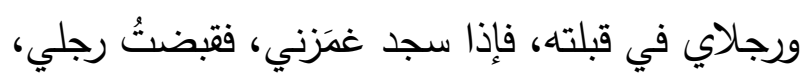

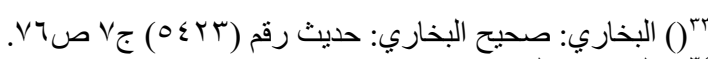

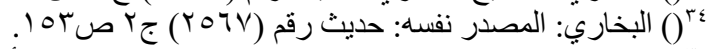

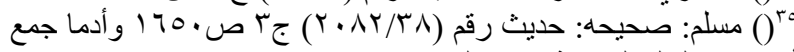
أديم وهو الجلد المدبوغ (نفس المصدر).

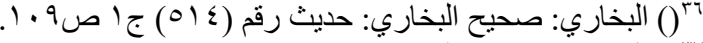

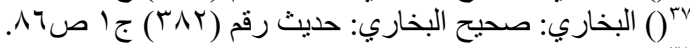

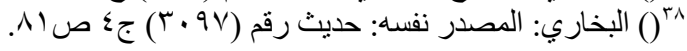


- • ابنة الخليفة عبد الملك بن مروان، لكنها لما أضحت بين يوم وليلة زوج الخليفة الزاهد، فوقفت بجواره معينة مخلصة، مستشعرة مسئوليتها تجاه زوجها الذي آثر ثواب الآخرة، ملتزما في ذلك بالزهد في زينة الدنيا وزخرفها، ولم تتردد فاطمة في الإختيار بين زوجها وبين ما يدعوها إليه من حياة جديدة قد تشق عليها. فقد ذكر أن عمر بن عبد العزيز لما ولي الخلافة وجد زوجته فاطمة تلبس عقدًا رائعًا من جوهر ثين كان أبوها عبد الملك قد أهداها إياه، فيتقدم إليها ويضعها أمام اختيار صعب فقال لها: اختاري. إما أن تردي حليك إلى بيت المال، وإما أن تأذني لي في فراقك؛ فإني أكره أن أكون أنا وأنت وهو في بيت واحد. قالت

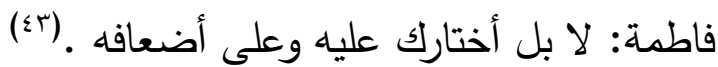
تلك هي المرأة التي يقول فيها الشاعر: بنت الخليفة والخليفة جدها ****** أخت الخلائف والخليفة زوجها .(ء ؟)

و الياً على الحجاز كلها، ثم عُزل عنها و انتقل إلى دمشق. فلما تولى سليمان

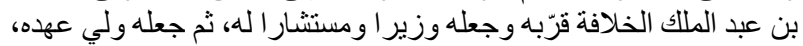

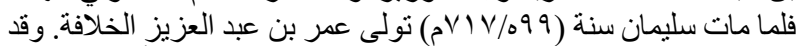

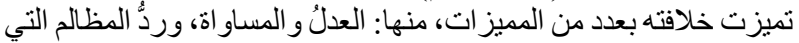

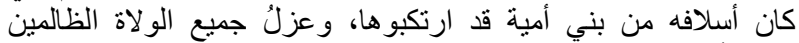

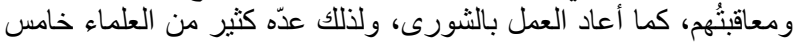

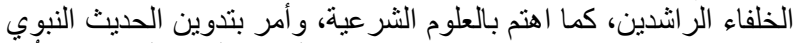

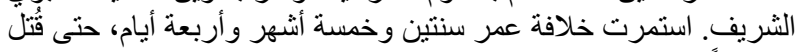

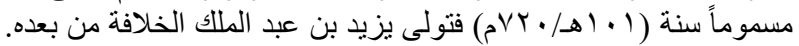

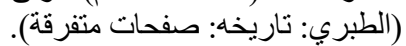

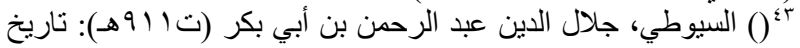

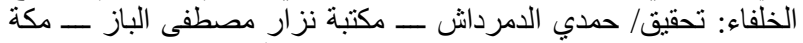

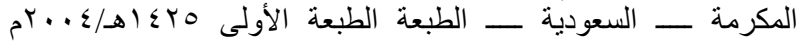

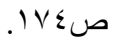

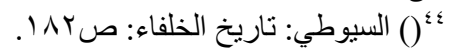

هذه النماذج تبين لنا حسن معاملة النبي (صلى الله عليه وسلم) لأزواجه، وعلينا أن نقتدي به، في أعماله، وأقواله، وأخلاقه، وكلِ جزئيات سلوكه في الحياة، فهو خير قدوة يقتدي نقتدي به، وقد جعل الله الذين آمنوا معه، وصدقوا، وأخلصوا، واستقاموا أمثلة رائعة يقتدى بها في معظم الفضائل الفردية والاجتماعية، ولئن انتقل الرسول (صلى الله عليه وسلم) إلى جوار ربه، فإنَّ سيرته التي تحتوي على جزئيات سلوكه ماثلة لنا، وفيما بلغنا من تراجم أصحابه رضوان الله عليهم ما يكفي لتجسيد القدوة الحسنة للمجتمع المسلم. المبحث الثاني

حسن التعامل بين الأزواج نماذج من العصر الأموي الأن اــ التضحية والوفاء وإذا تحدثا عن مثال آخر من نماذج التضحية والوفاء، فلنتحدث عن زوجة من الزوجات الصالحات التي خلد التاريخ ذكرها وهي فاطمة بنت عبد الملك(اء) زوجة

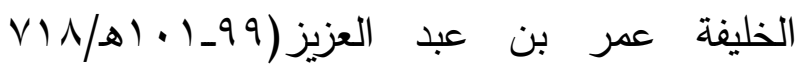

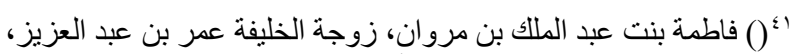

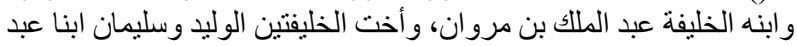

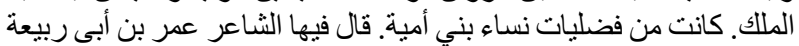

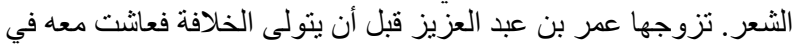

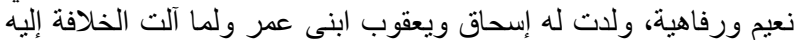

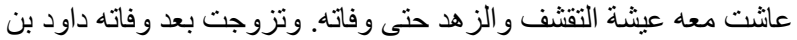

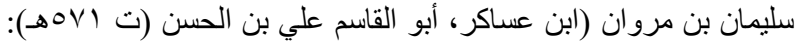

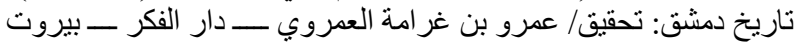

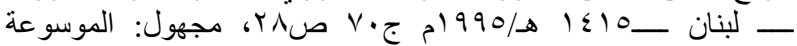

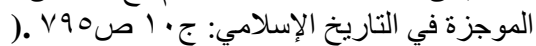

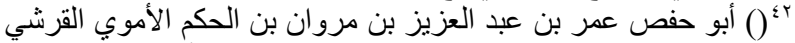

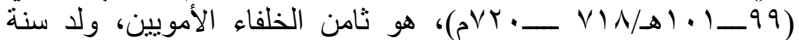

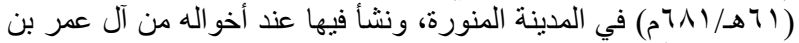

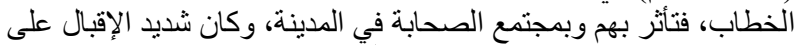

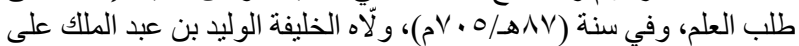

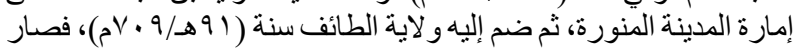


لا يملك سواه وتعجن وتطهو الطعام، راضية النفس

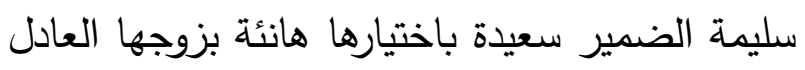
البسيط الزاهد في متاع الدنيا. ويشير إلى بساطة الحياة التي كانت فيه مع زوجها: لترانيا

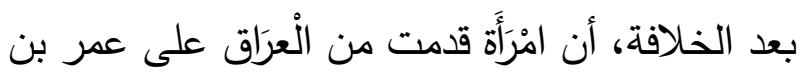

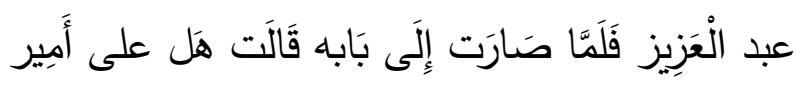

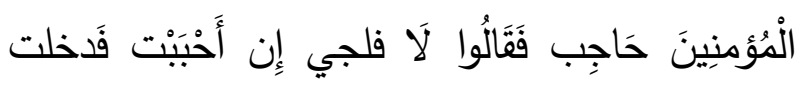

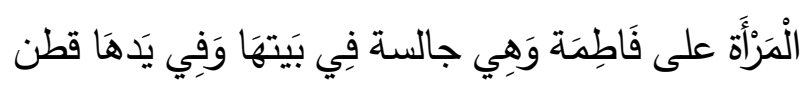

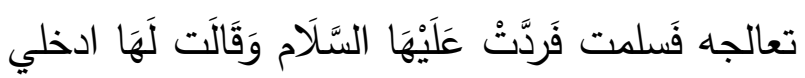

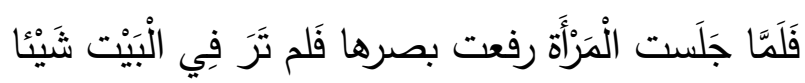

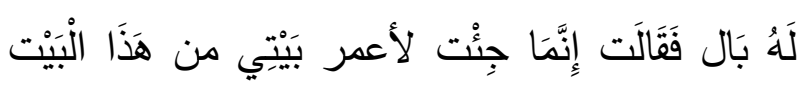

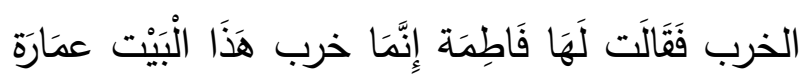

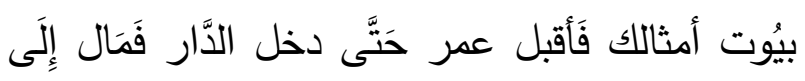

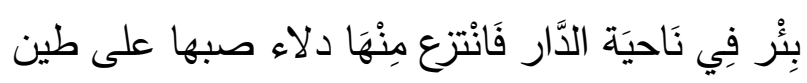

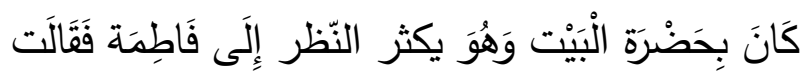

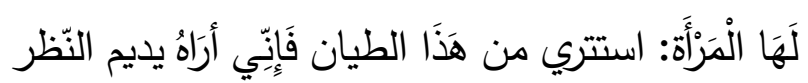

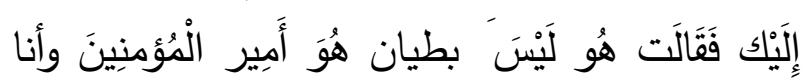
زوجته فاطمة. (\&v) ومن يصدق أن الخليفة عمر بن عبد العزيز لا يملك

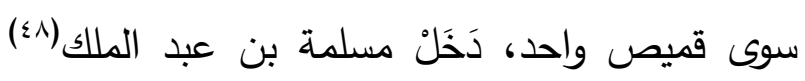

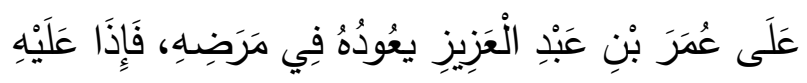

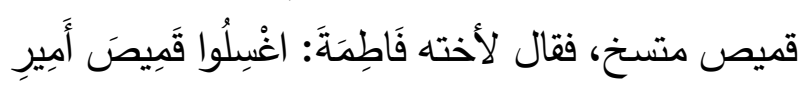

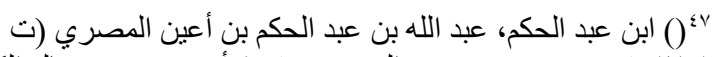

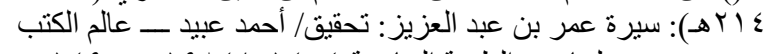

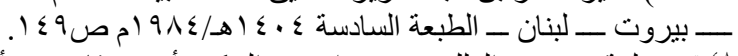

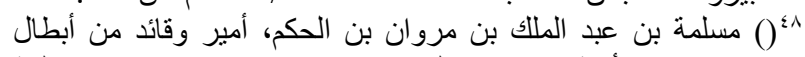

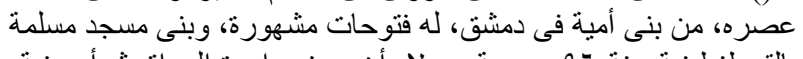

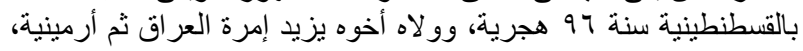

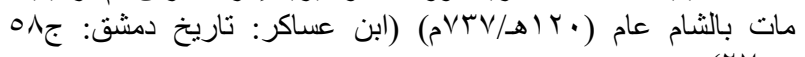

ذلك هو الوفاء، وهذه هي التضحية، ويمتد ذلك الوفاء

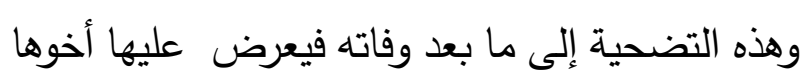

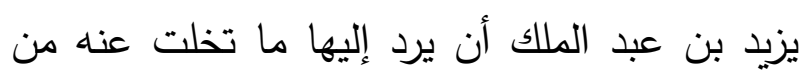

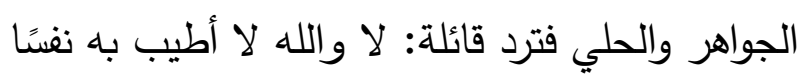

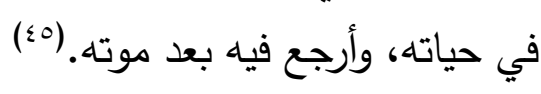

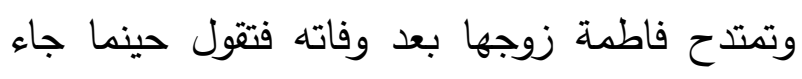

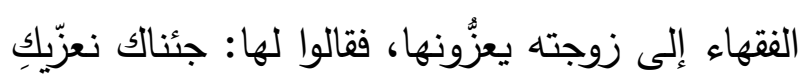
بعمر، فقد عمَّت مصيبةُ الأمة، فأخبرينا يرحمكِ الله عن عمر كيف كانت حالُه في بيته، فإن أعلم النَّاسِ بالرجل أهلُه. فقالت: واللهِ ما كان عمرُ بأكثرِمِ صلاةً

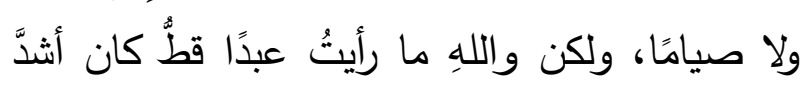

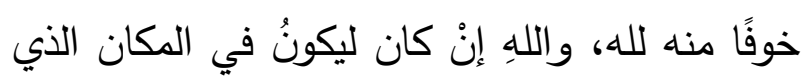
ينتهي سرورُ الرجلِ بأهله، [بيني وبينه لِحاف] فيخطرُ لئه

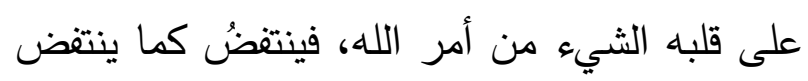
الطائر إذا وقع في الماء، ثم ينشج ويرتفع بكاؤه حتَّى التى أقول: خرجت نفسُه، فأطرحُ اللِّحاف عني وعنه رحمةً

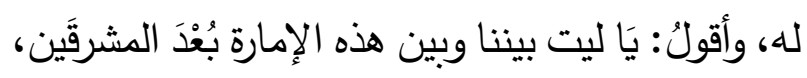

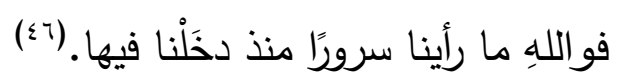
r- بـ العيش الزهيد. كانت فاطمة بنت عبد الملك زوجة الخليفة عمر بن عبد العزيز سيدة القصور قد تحولت حياتها من سيدة

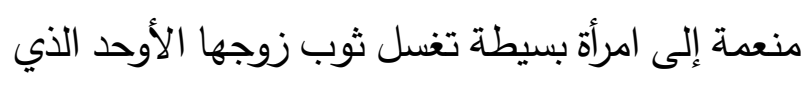

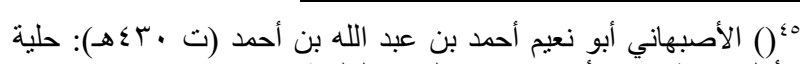

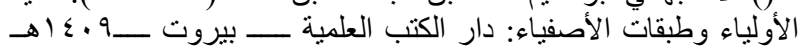

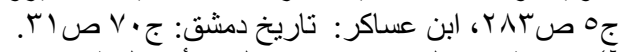

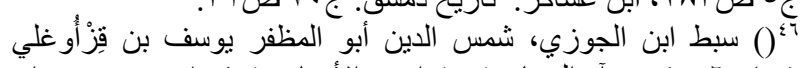

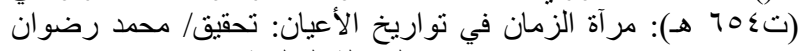

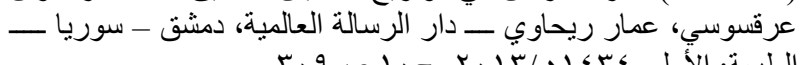




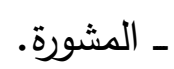

وننتقل إلى العصر العباسي لنرى صورًا من معاملة

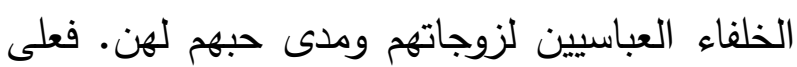

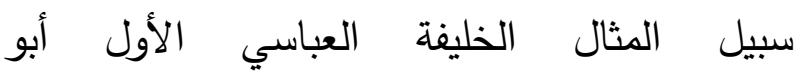

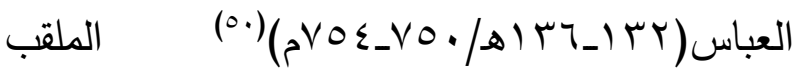

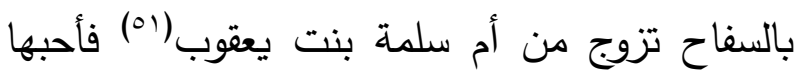
وتمكنت من قلبه، وحظيت عنده حتى حلف ألا يتزوج

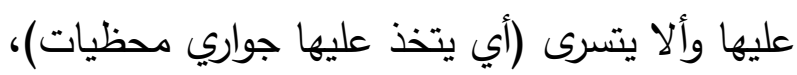

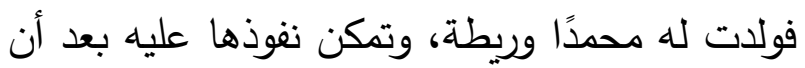
أنجبت منه، ولما قامت الدولة العباسية وأصبح الخليفة ولهن كان لا يقطع أمرًا إلا بمشورتها، ولم يكن يدنو إلى لـألى

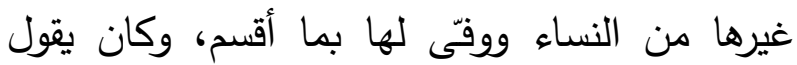

لجلسائه:"اتركوا الحديث في النساء والطعام".(or)

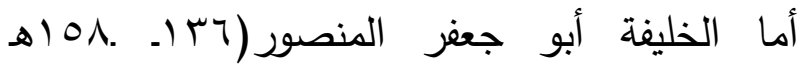

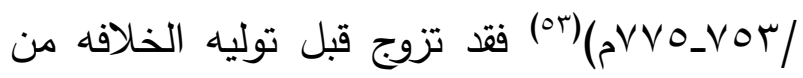
أروى القيروانية(ْ)، فاشترطت عليه ألاّ يتزوج عليها

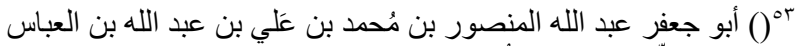

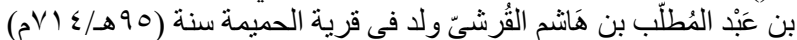

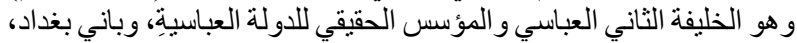

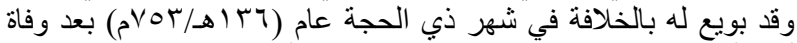

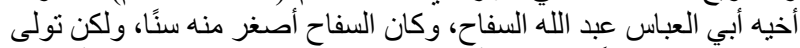

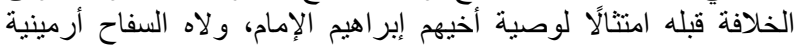

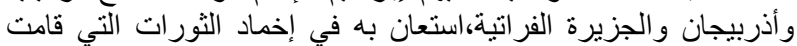

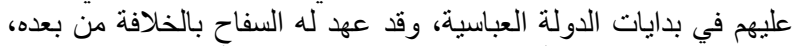

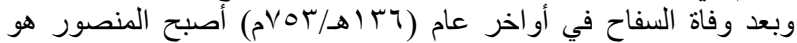

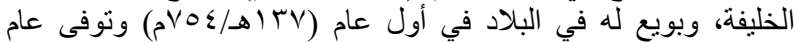

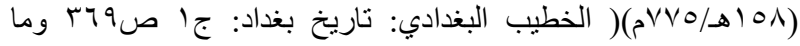

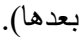

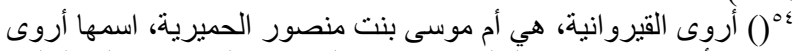

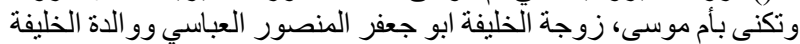

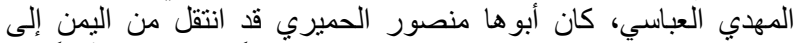

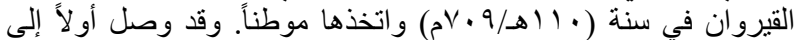

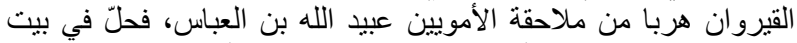

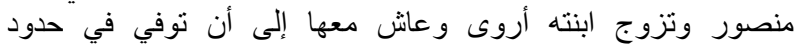

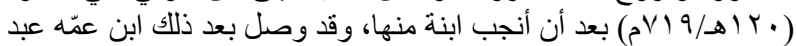
الله بن العباس ( الذي عرف فيما بعد الخليفة أبو جعفر المنصور العباسي)

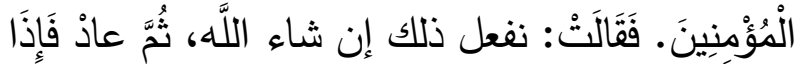

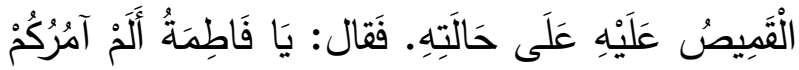

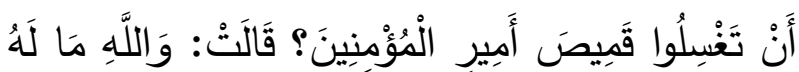

قَمِيصٌ غَنَيْهُه. بعد ذكر هذه النماذج التي ذكرتها أساءلٌ نفسي. هل توجد امرأة في زماننا هذا ترضى أن تعيش مع زوجها في مثل هذه الظروف؟ الإجابة ستكون لا. ولا أستطيع إلا القول بأن هؤلاء أتعبوا من جاء بعدهم، فرضي الله عن أمهات المؤمنين، فكن قدوة صالحة للنساء على مر التاريخ، ورحم الله فاطمة بنت عبد الملك فكانت امرأة قل أن يجود الزمان بمثلها، ومثلها فلتكن النساء في كل زمان. المبحث الثالث

حسن التعامل بين الأزواج نماذج من العصر

$$
\text { العباسي }
$$

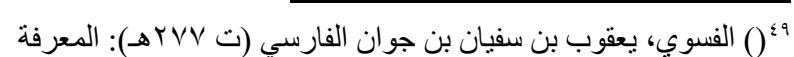

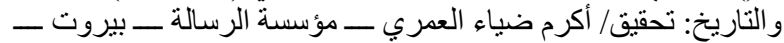

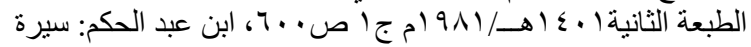

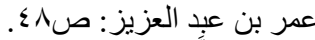

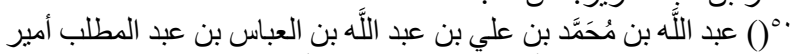

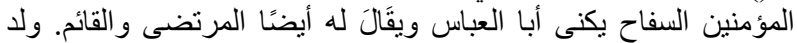

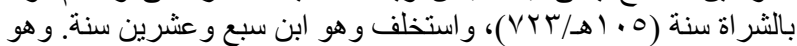

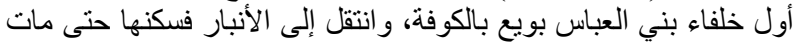

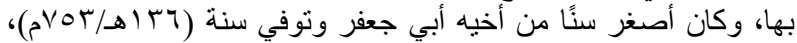

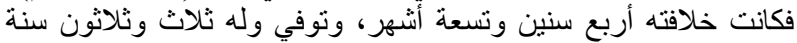

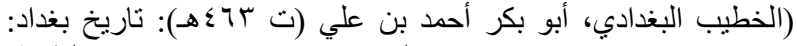

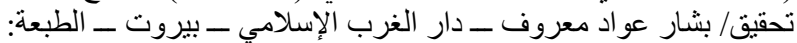

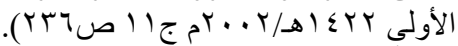

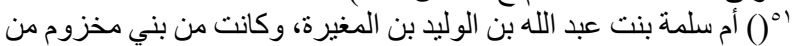

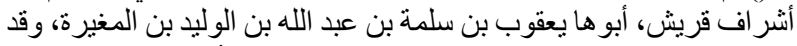

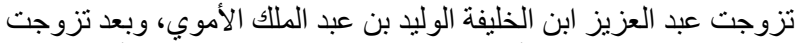

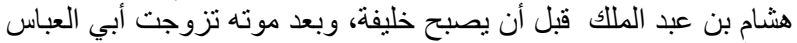

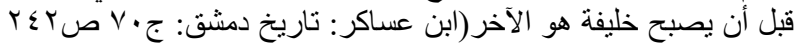

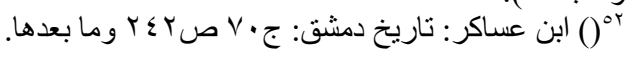


ضربن أروع الأمثلة في المعاملة الحسنة من حب لأزواجهم والتضحية والوفاء من أجلهم والصبر على الى الهاء ضيق العيش. أما العصر الأموي فكانت زوجة الخليفة عمر بن عبد العزيز امتدادًا للعصر السابق فاستحقت أن يخلدها التاريخ. وفي العصور الأولى لم يكن هنالك تدخل للنساء مطلقًا في شئون الحكم، على خلاف العصر العباسي الذي

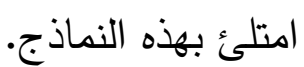
فبسبب حب الخلفاء وعشقهن للنساء فإنهن صرن يتحكمن في أمور الدولة وفي ولاية العهد، وغيرها من الأمور الحساسة التي جرت الويلات على الخلافة العباسية من قتل الأخ لأخيه، وكثرة التمردات وغيرها وذلك كله بسبب تدخل النساء في أمور الدولة. أما إذا أردنا أن نقارن بين مكانة المرأة قبل الاسلام وبعده، فيمكننا القول: أنه ومنذ المراحل الأولى من تاريخ التطور البشري في عهد الرق والعبودية كانت المرأة تعاني من ظلم الرجل، الذي كان يمضي حياته

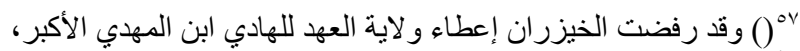

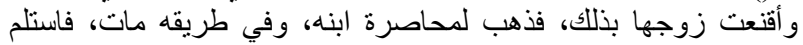

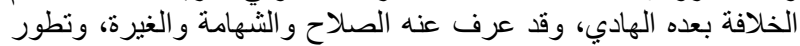

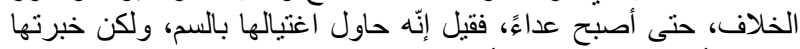

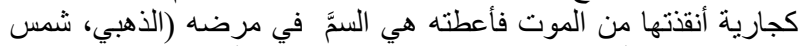

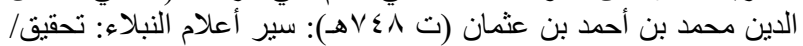

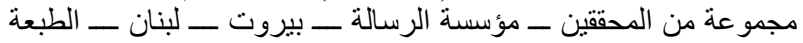

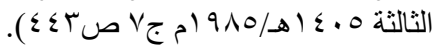

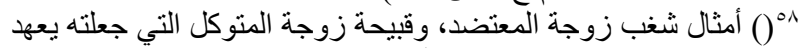

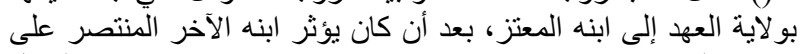

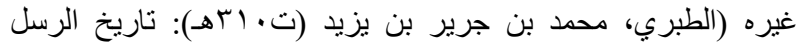

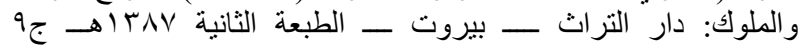

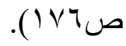

وألاّ يتخذ عليها سرائر ، ووفّى لها أبو جعفر حتى بعد أن تولى الخلافة، ولم يتزوج إلا بعد أن ماتت زوجته. (00) تول

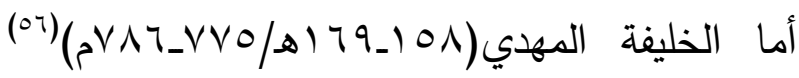
فقد تزوج من الخيزران بنت العطاء، وهي جارية استقدمت من اليمن إلى قصر الخليفة العباسيّ المهديّ، فأعتقها وتزوّجها، وأحبها حبًا شديدًا، حتى لئى أنها صارت تتحكم في مقاليد الأمور، ولم تكن واعن الخيزران كغيرها من النساء، ولم تكن شهرتها من فراغ،

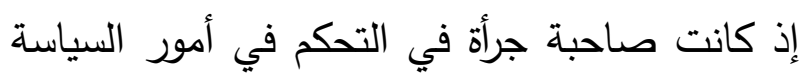

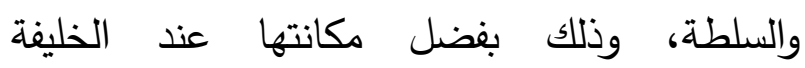

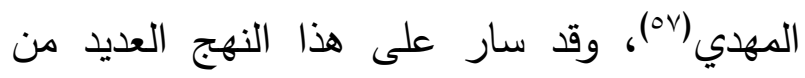
زوجات الخلفاء العباسيين.، وهاري

وإذا أردنا أن نقارن بين معاملة الأزواج خلاء عصر النبوة والخلافة الراشدة والعصر الأموي من ناحية، لنانية وبين العصر العباسي من ناحية أخرى. لاستطعنا القول أن زوجات عصور النبوة والخلافة الراشدة

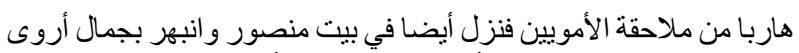

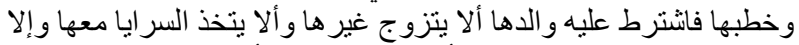

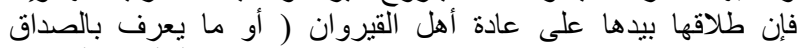

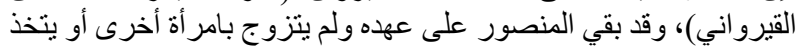

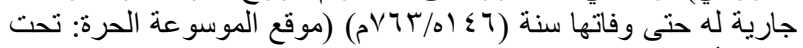

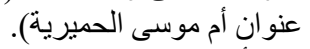
0( أمل الكردي: دور النساء في الخلافة العباسية: دار اليازوري _ عمان

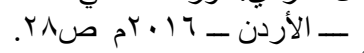

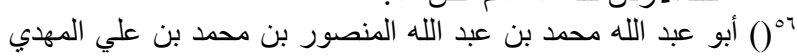

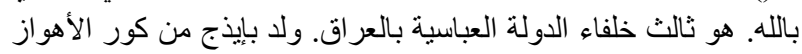

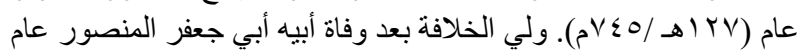

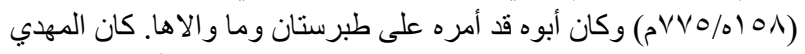

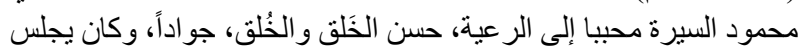

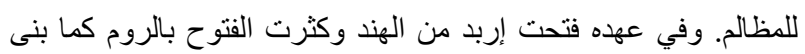

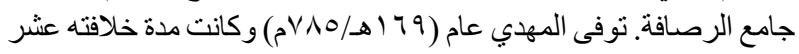

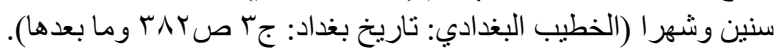


أما المرأة عند الرومان: كان شعارهم فيما يتعلق بالمرأة:

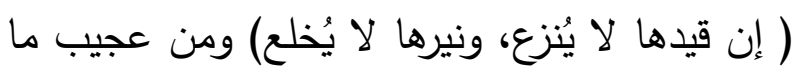

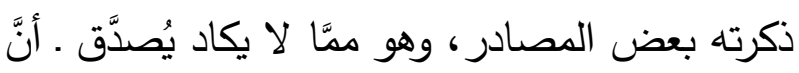

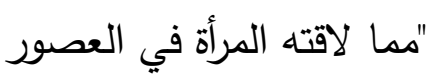
الرومانية، تحت شعارهم المعروف: (ليس للمرأة روح)

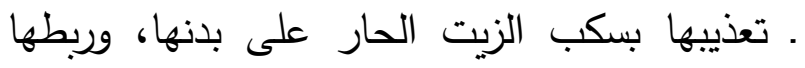

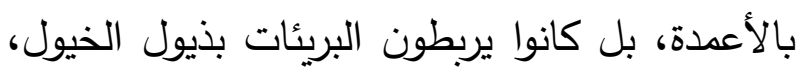

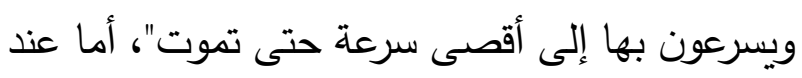

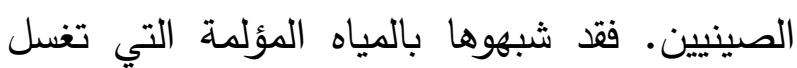
السعادة والمال، وللصيني الحق في أن يبيع زوجته لئه

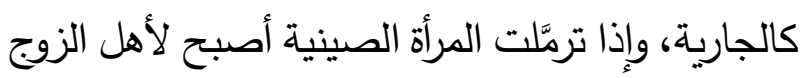
الحق فيها كثروة تورث، وللصيني الحق في أن يدفن

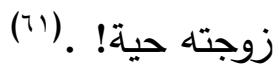

أما عند الهنود: فلم يكن للمرأة في شريعة منو حق في الاستقلال عن أبيها أو زوجها أو والدها، فإذا مات لثنات

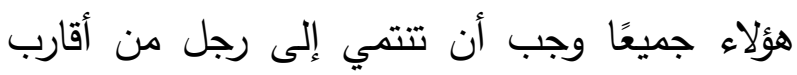

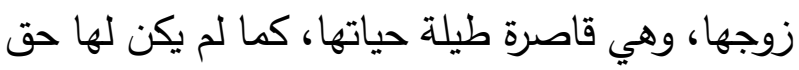
في الحياة بعد وفاة زوجها بل يجب أن تحرق معهد وهي حية على موقد واحد، وقد استمرت هذه العادة حتى القرن السابع عشر ، كما كانت تقدم قربانا للألهاة لترضى ، وقد جاء في شرائع الهنود:( ليس الصبر

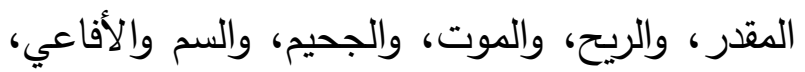

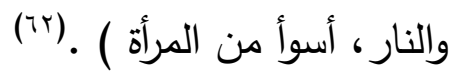

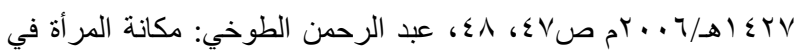

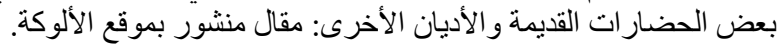

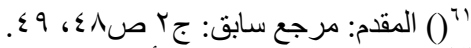
ז () مصطفى السباعي: المر أة بين الفقه و القانون: دار السلام ــ القاهرة
في الصيد، فكانت حارسة لحجرها وحامية لأولادها من

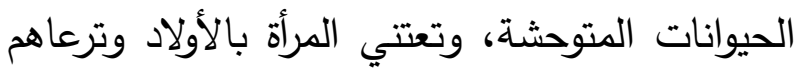
وتقوم بتأمين الاحتياجات الضرورية لها ولأطفالها وكان من مهامها جمع الحطب وإشعال النار وتأمين الدفء وإعداد الطعام، والخروج إلى الصيد في غياب الرجل، ثم أصبحت تباع وتشترى وتسخر ليل نهار

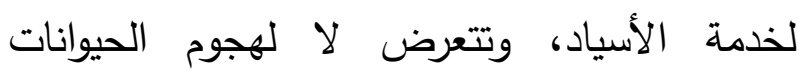
المتوحشة والبرية فحسب بل لهجوم الرجال وظلمهم وثم تتعرض للمهانات وتعمل في الأعمال الشاقة

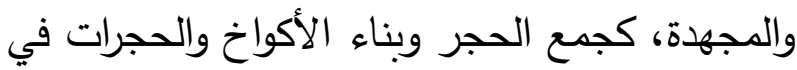
الجبال والكهوف . (ه) ولننظر إلى حال المرأة في الجاهليات القديمة و ولهوب العصور الوسطى، وكيف ينظرون إلى المرأة، هل هي

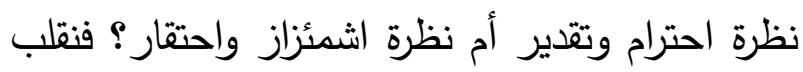
شينًا من صفحات الأمم السابقة لنرى كيف هو كلامهم عن المرأة، وكيف أنَّهم يجردون هذه المرأة من جميع حقوقها الإنسانية : ـ المرأة عند الإغريق: كانت محتقرة مهينة، حتى إنَّهم ليعدونها رجسًا من عمل الشيطان، وكانت عندهم كسقط المتاع فتباع وتثترى في الأسواق. قال سقراط: ( إنَّ وجود المرأة هو أكبر منشأ ومصدر للأزمة والانهيار في العالم، إنَّ المرأة تشبه شجرة مسمومة

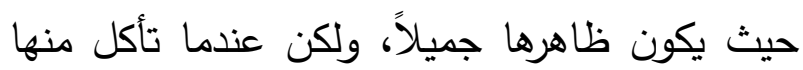

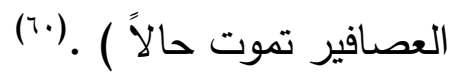

9๑告 شيرين الضاني: عمل المر أة في الإسلام: مقال منشور بموقع الحوار

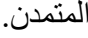

") () محمد إسماعيل المقدم: عودة الحجاب(المر أة بين تكريم الاسلام و إهانة

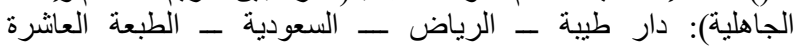


تحت سلطة الرجل المطلقة، يحق له أن يحكم عليها

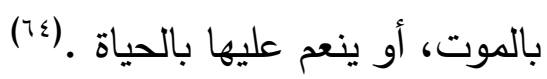
أما المرأة عند اليهود: فكانت إذا حاضت عهيت بالهي نجسة

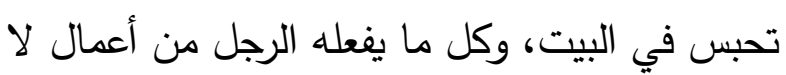
أخلاقية قائمة على المرأة، فعن أنس ابن مالك رضي الله عنه:" أن اليهود كانوا

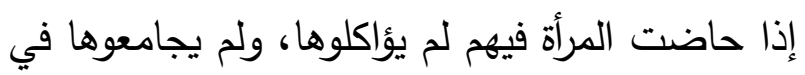
البيوت، فسأل الصحابة ـ رضي الله عنهم ـ النبي -

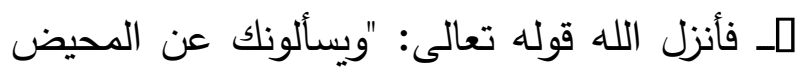

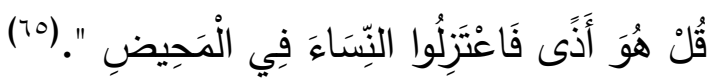
كما كان ينظر إليها على أنَّها في مرتبة الخدمة، ولأبيها

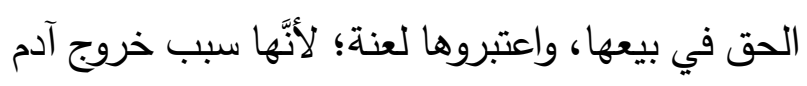
من الجنة عندما أغوته بزعمهم.

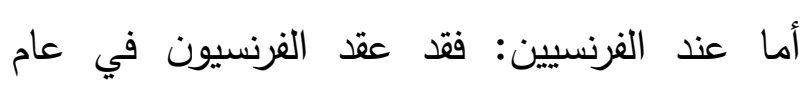

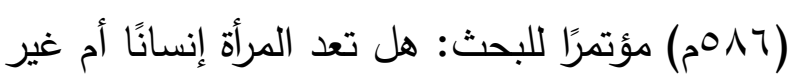
إنسان؟! وهل لها روح أم ليست لها روح؟ وإذا كانت لها روح فهل هي روح حيوانية أم روح إنسانية؟ وإذا كانت روحًا إنسانية فهل هي على مستوى روح روح الرجل

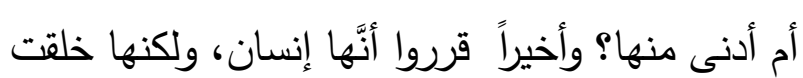

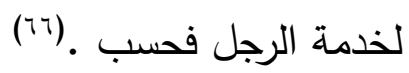
أما مكانة المرأة العربية في العصر الجاهلي، فقد

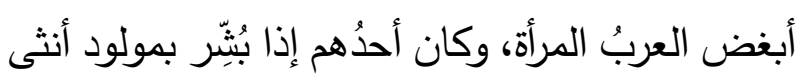

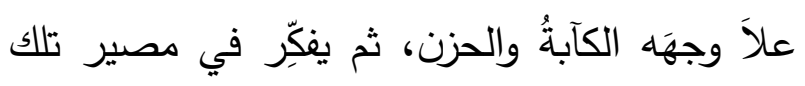

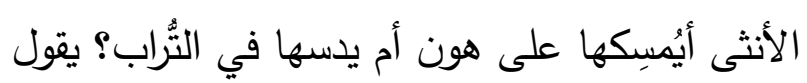

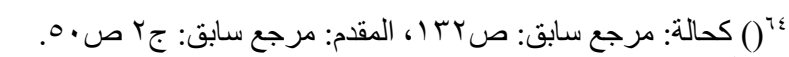

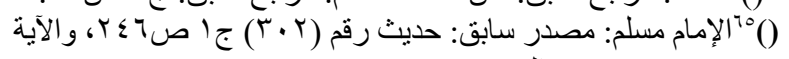

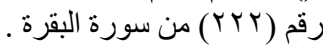

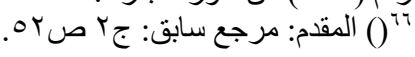

فالمرأة عند الهنود أسوأ من كل الأمور السابقة، وهذا إجحاف بحق المرأة.

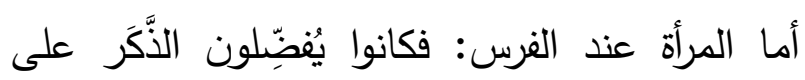

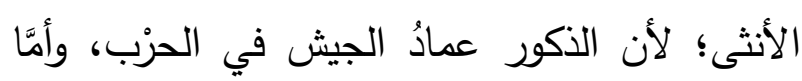

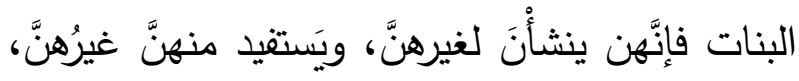

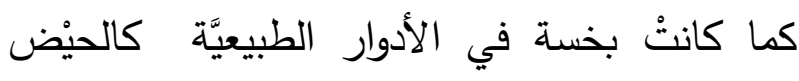
والنّفاس ، يُبعدن في وقَتِه عن المنازل، ويَقِمْنَ في خيام صغيرة تُضرب لهنَّ في ضواجِي المدينة أو البلدة، ولا

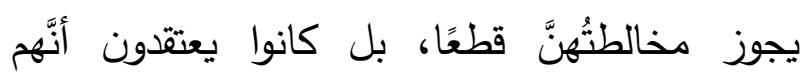
يتتحسون إذا مسُوهنَّ أو مسُّوا الخيام أو الأشياء المحيطة بهنَّ، وخضَعَتِ المرأة الفارسية القديمة

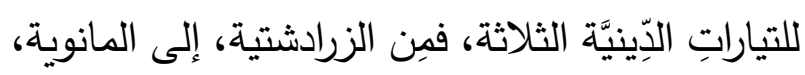
إلى المزدكية، وقد تركتُ كلُّ ديانة من هذه الديانتات بصمتَها الواضحة على كيان الأُسرة، تعيش في ذلِّ لِّ وقهز واستعباد. لri) وكانتِ النساء الفرس تحسَّ سُلطة الرجل المطلَقة الذي وَّي يحقُّ له أن يحكُمَ عليها بالموت، أو ينعم عليها بالحياةِ

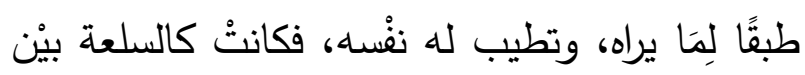
يديه، كما أبيح الزواج بالأمهات والأخوات والعمات

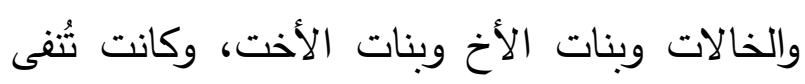

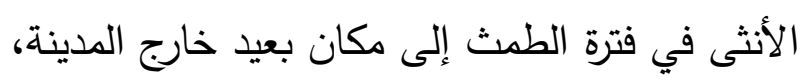

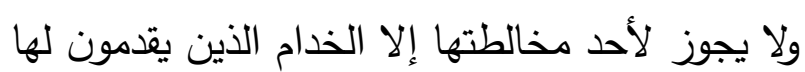
الطعام، وفضلاً عن هذا كله فقد كانت المرأة الفارسية

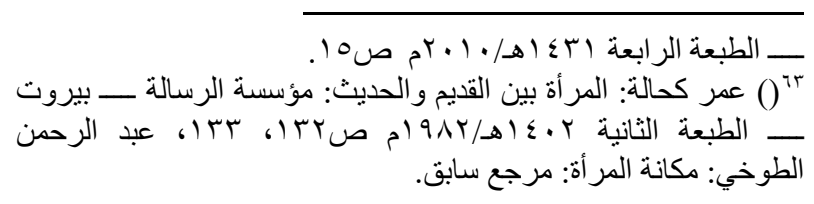


والذي تسمعون به هو صغير الثعبان" ، وأصدر

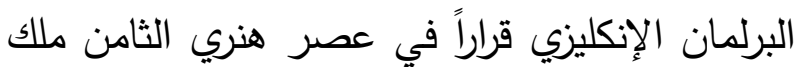
إنكلترا يحظر على المرأة أن تقرأ كتاب (العهد الجديد)

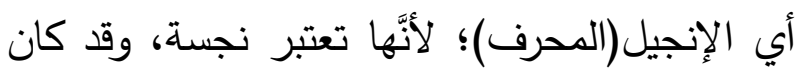

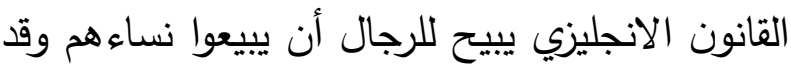

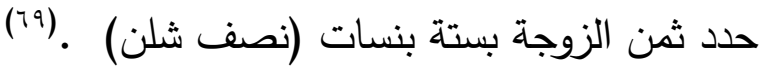
وفي النهاية يمكن القول: أنه ليس هناك دِينًا كرَّم

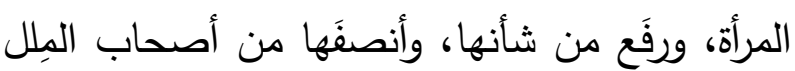
الأخرى إلا الإسلام، حيث وضع الرَّجل والمرأة على لقى

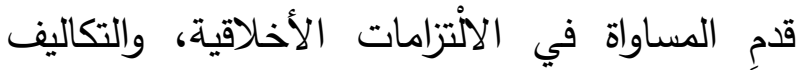
الدينية إلا في حالات مخصوصَّة خفَّف الله فيها عن ولهن

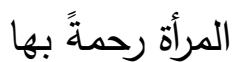
كما أنزل الله أحكامًا خاصَّة بالنِّساء وأنزل سورةً

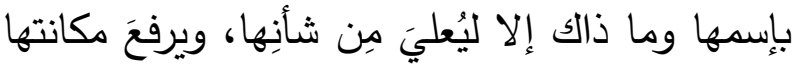

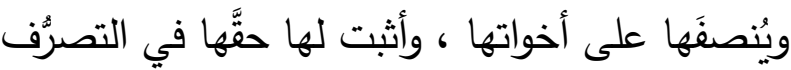
ومباشرة جميع الحقوق كحقّ البيع وحقِّ الشراء وحقّ الراهن وحقّ المرتهن وكل هذه الحقوق واجبةُ، ولم يعتبرِ الإسلام المرأةَ جرثومةً خبيثة كما اعتبرَها

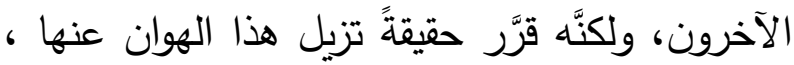
وهي أنَّ المرأة بين يدي الإسلام قسيمةُ الرجل، مصداقًا

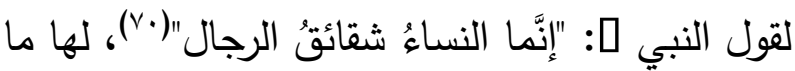
له من الحقوق، وعليها أيضًا من الواجبات ما يُلائم

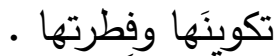

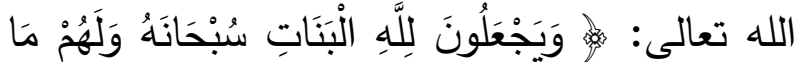

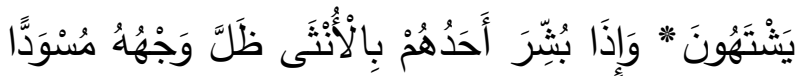

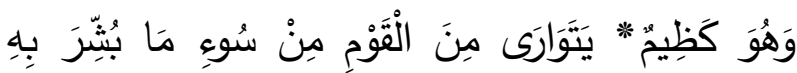

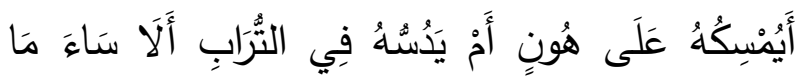
(TV). يَحْكُمُونهِ كما كان العرب في الجاهلية ينظرون إلى المرأة على أنها متاع من الأمتعة التي يمتلكونها مثل الأموال والبهائم، ويتصرفون فيها كيف شاؤوا، وكان العرب لا لا لأل يورثون المرأة، ويرون أن ليس لها حق في الإرث وكانوا يقولون: لا يرثنا إلا من يحمل السيف، وكذلك لم يكن

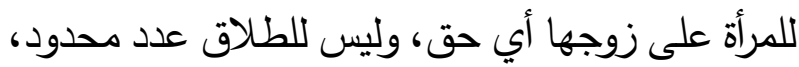
وليس لتعدد الزوجات عدد معين، وكان العرب إذا مات الرجل وله زوجة وأولاد من غيرها كان الولد الأكبر أحق بزوجة أبيه من غيره، فهو يعتبرها إرثًا كبقية أموال أبيه، فعن ابن عباس - رضي الله عنه عنها

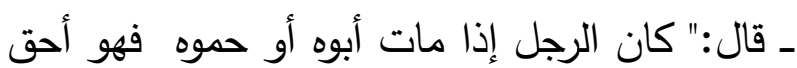

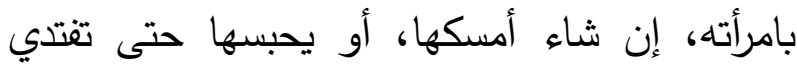

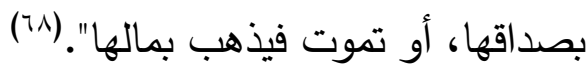

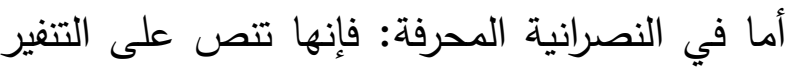
من المرأة وإن كانت زوجة، واحتقار الصلة الزوجية

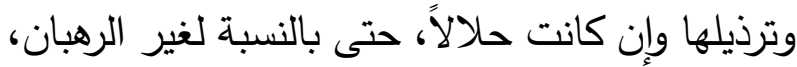
بقول أحد رجال الكنيسة (بونافتور) الملقب بالقديس:"

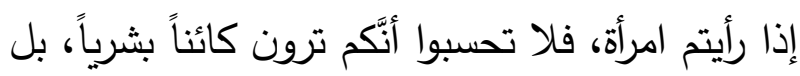

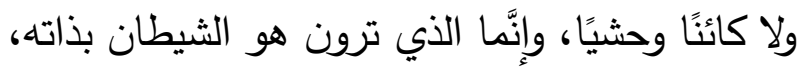

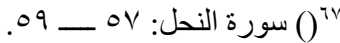

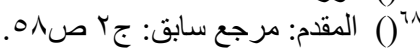

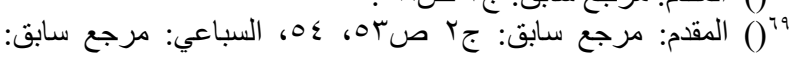


جدول يبين أسماء الرجال والفترة الزمنية لعناصر الدراسة

\begin{tabular}{|c|c|c|c|c|}
\hline الوفاة & فترة الحكم & تاربخ الميلاد & الاسم & 5 \\
\hline 11) & & pov1/... & النبي محمد & $\underline{1}$ \\
\hline 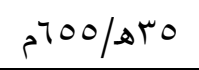 & & & 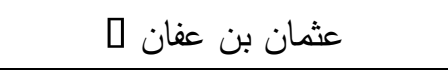 & $\underline{\mathbf{2}}$ \\
\hline (2) & $5 V Y \cdot-V / N / 81 \cdot 1-99$ & 197/ & عمر بن عبد العزيز & $\underline{\mathbf{3}}$ \\
\hline $5^{V 0 \leqslant / 81 Y 4}$ & 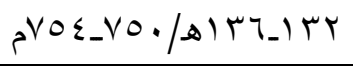 & 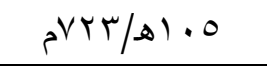 & الخليفة العباسي الأول أبو العباس & $\underline{4}$ \\
\hline pVO/8101 & 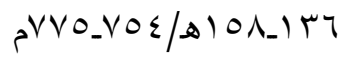 & O90 90 & أبو جعفر المنصور & $\underline{\mathbf{5}}$ \\
\hline 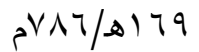 & ¿V人T_VVO/ه179_101 & 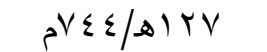 & الخليفة المهدي & $\underline{6}$ \\
\hline
\end{tabular}

جدول يبين أسماء النساء والفترة الزمنية لعناصر الدراسة

\begin{tabular}{|c|c|c|}
\hline الفترة الزمنية & 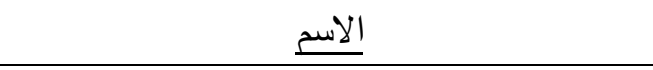 & 5 \\
\hline 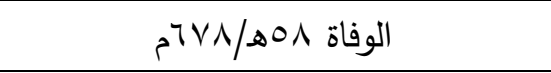 & السيدة عائشة زوجة النبي Q & $\underline{1}$ \\
\hline 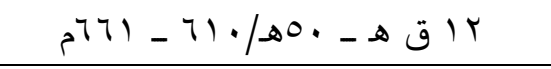 & السيدة صفية بنت حيي زوجة النبي 0 & $\underline{\mathbf{2}}$ \\
\hline كTr ق. هـ _- & السيدة زينب بنت جحش زوجة النبي & $\underline{\mathbf{3}}$ \\
\hline 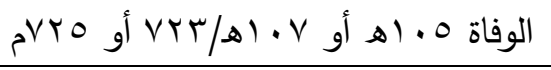 & فاطمة بنت عبد الملك & $\underline{4}$ \\
\hline لم يعرف لها تاريخ ولادة أو وفاة & أم سلمة زوجة الخليفة العباسي الأول أبو العباس & $\underline{\mathbf{5}}$ \\
\hline 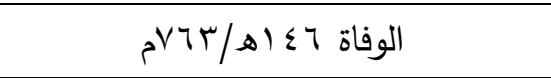 & أروى القيروانية زوجة أبو جعفر المنصور & $\underline{6}$ \\
\hline 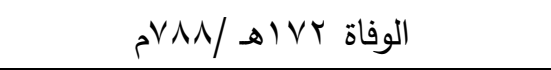 & الخيزران زوجة المهدي & $\underline{7}$ \\
\hline
\end{tabular}

والملاطفة والتضحية والوفاء وغيرها من الصفات الحسنة دون التدخل في أمور السياسية، مما كان له وله وله أعظم الأثر من نشر المحبة والألفة بين أفراد الأسرة الواحدة بل بين أفراد المجتمع ككل. ـ ضرب لنا النبي (صلى الله عليه وسلم) أروع الأمثلة في حسن معاملته لأزواجه، فرغم أعباء الدعوة ومشاقها كان(صلى الله عليه وسلم) يثفق أن تراه زوجاته عابًًا في وجوههن، بل كان ألين الناس وأكرم الناس.

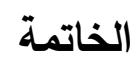

ألقت هذه الدراسة الضوء على حسن معاملة الأزواج

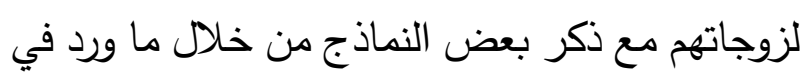
بعض المصادر والمراجع، وقد استخلصنا من بحثنا هذا جملة من الاستتتاجات الهامة التي يمكن حصرها في ما يلي: ـ كانت المعاملة بين الأزواج خلال عصر النبوة والخلافة الراشدة قائمة على حسن الخلق والمحبة الأولاج 
1 الكامل في التاريخ: تحقيق/ عمر عبد السلام تدمري ـ

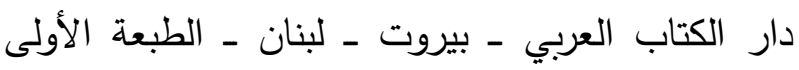
. $99 \mathrm{~V} / \mathrm{S}) \leq 1 \mathrm{~V}$

أحمد بن حنبل، أبو عبد الله أحمد بن محمد

$$
\text { : (ت ب) }
$$

r- مسند الإمام أحمد: تحقيق/ شعيب الأرنؤوط وآخرون

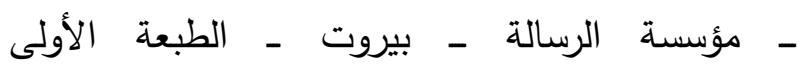

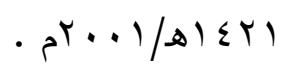

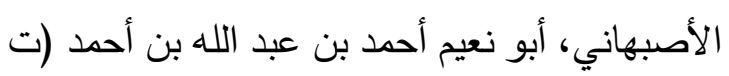

rـ حلية الأولياء وطبقات الأصفياء: دار الكتب العلمية ـ

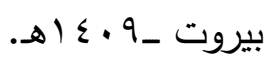

• الألباني، أبو عبد الرحمن محمد ناصر الدين (ت أهرو

:(ه) $\leqslant$ r.

عـ صحيح الجامع الصغير وزياداته: المكتب الإسلامي ـ

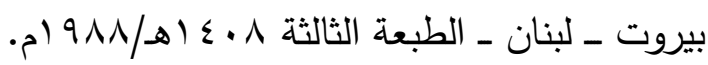
البخاري، أبو عبد الله محمد بن إسماعيل

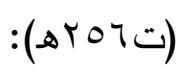

○ـ الجامع المسند الصحيح المختصر من أمور رسول الله صلى الله عليه وسلم وسننه وأيامه أو(صحيح البخاري): تحقيق/ محمد زهير بن ناصر الناصر ـ دار طوق النجاة

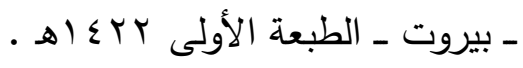

الترمذي، محمد بن عيسى بن سَوْرة بن موسى التى

$$
\text { (ت ه }
$$

T- سنن الترمذي: تحقيق وتعليق/ إبراهيم عطوة عوض -

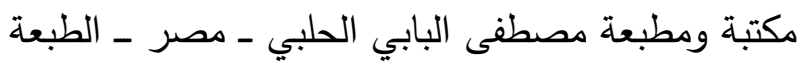

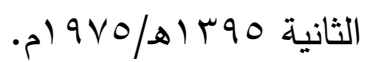

ـ أثبت البحث أن الخليفة عمر بن عبد العزيز وزوجته فاطمة بنت عبد الملك ضربا لنا أروع الأمثلة في الوفاء والتضحية والزهد فكانت زوجته قدوة صالحة للنساء على مر التاريخ، فرحم الله فاطمة بنت عبد الملك ولك فكانت امرأة قل أن يجود الزمان بمثلها، ومثلها فلتكن النساء في كل زمان. ـ أثبت البحث أن المعاملة بين الخلفاء وزوجاتهم في العصر العباسي تحول إلى عشق للنساء مما جعل النساء صرن يتحكمن في أمور الدولة مما سبب الكثير

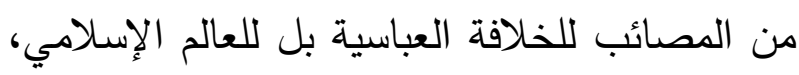
وجعل العلاقة داخل الأسرة الواحدة من بيت الخلافة

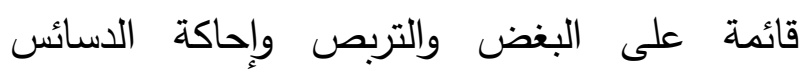
والمؤامرات بدلًا من الحب والألفة والمودة التي انتشرت في عصر النبوة والخلافة الراشدة. التوصيات

يوصي الباحث بالتعمق في دراسة المعاملة الحسنة بين الأزواج عبر العصور المختلفة، وإبراز الجوانب

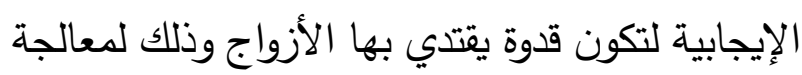
مشاكل المجتمعات الإسلامية.

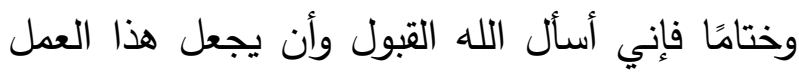
خالصًا لوجهه الكريم. المصادر والمراجع

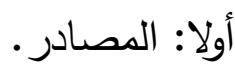
القرآن الكريم ابن الأثير : أبو الحسن علي بن أبي الكرم محمد بن

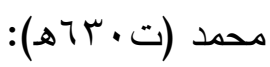


r ا ـ تاريخ الخلفاء : تحقيق/ حمدي الدمرداش ـ مكتبة نزار مصطفى الباز ـ مكة المكرمة ـ السعودية ـ الطبعة الطبعة

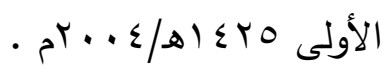
ابن شبة، أبو زيد عمر بن شبة النميري البصري

با- تاريخ المدينة المنورة: تحقيق/ علي محمد دندل وياسين سعد الدين بيان ـ دار الكتب العلمية ـ بيروت ـ

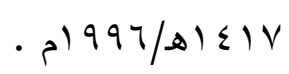

الصالحي، محمد بن يوسف الصالحي الثامي (ت اله

$$
: \text { (ه } 9 \leqslant \text { r }
$$

ع أـ سبل الهدى والرشاد، في سيرة خير العباد، وذكر فضائله وأعلام نبوته وأفعاله وأحواله في المبدأ والمعاد: تحقيق وتعليق/ عادل أحمد عبد الموجود، علي محمد الكداله معوض ـ دار الكتب العلمية بيروت ـ لبنان ـ الطبعة عادل علدئ

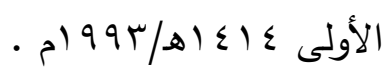

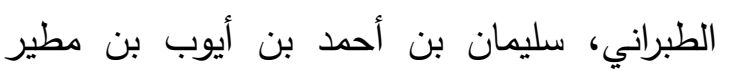

$$
\text { اللخمي (ت . ب آهـ): }
$$

1 1 ـ المعجم الكبير : تحقيق/ حمدي بن عبد المجيد السلفي ـ مكتبة ابن تيمية ـ القاهرة ـ الطبعة الثانية. الطبري، محمد بن جرير بن يزيد (ت • آتهـ): 17 ـ ـ تاريخ الرسل والملوك: دار التراث ـ بيروت ـ الطبعة

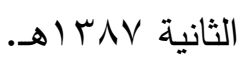
ابن عبد الحكم، عبد الله بن عبد الحكم بن أعين

$$
\text { المصري (ت ع آبه): }
$$

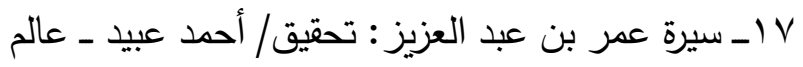

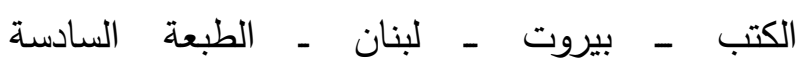

$$
\text { • مات }
$$

ابن الجوزي، جمال الدين أبو الفرج عبد الرحمن بن

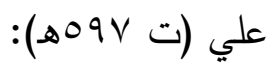

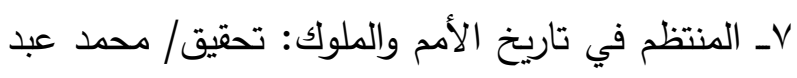

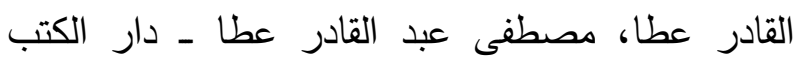

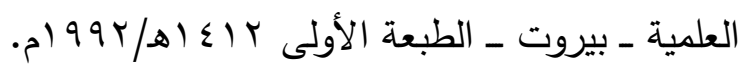

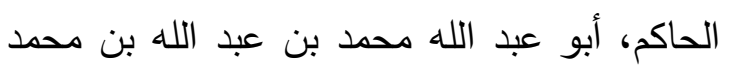

$$
\text { النيسابوري (ت م. • §ه): }
$$

^ــ المستدرك على الصحيحين: تحقيق/ مصطفى عبد اله

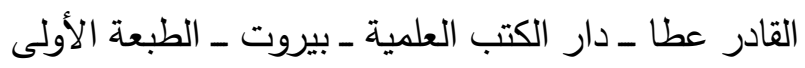
• م $199 \cdot / 1 \leq 11$ أبو داود، سليمان بن الأشعث بن إسحاق بن بشير

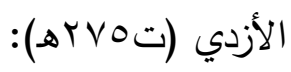
9ـ سنن أبي داود: تحقيق/ محمد : محد محيي الدين عبد الحميد

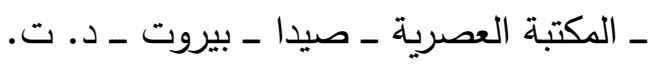

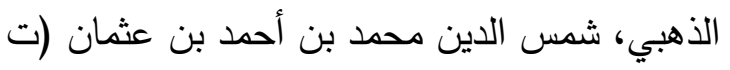
$:(ه \vee \wedge$ • ـ سير أعلام النبلاء: تحقيق/ مجموعة من المحققين -

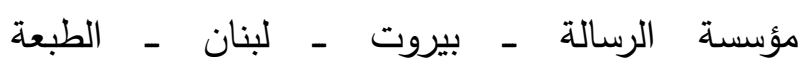

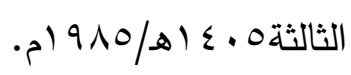

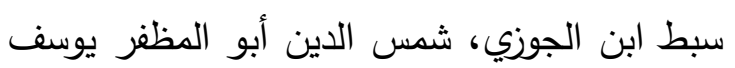

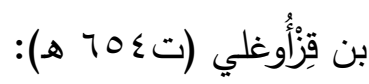

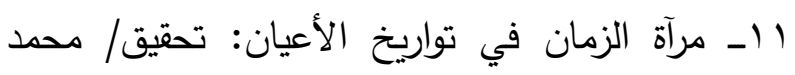

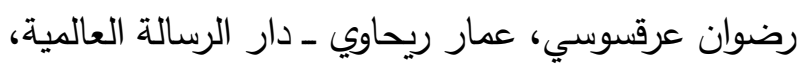

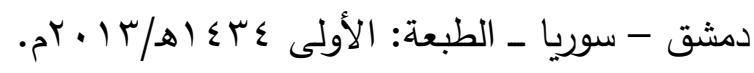
السيوطي، جلال الدين عبد الرحمن بن أبي بكر الأبراكر (ت) - (ت الم) (1) 
rץ-_ السنن الكبرى: حققه وخرج أحاديثه: حسن عبد المنعم

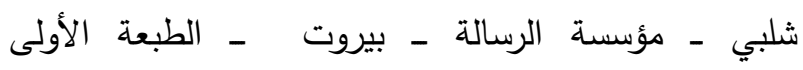

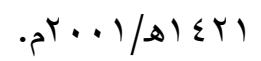

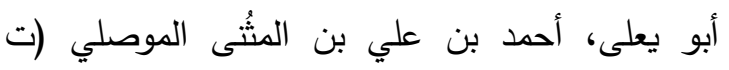

:

؟ Y_ مسند أبي يعلى: تحقيق/ حسين سليم أسد ـ دار المأمون

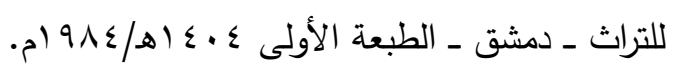

$$
\text { • المراجع. }
$$

هب_ دور النساء في الخلافة العباسية: دار اليازوري ـ عمان ـ

$$
\text { الأردن - } 17
$$

$$
\text { شيرين الضاني: }
$$

דr- عمل المرأة في الإسلام: مقال منشور بموقع الحوار

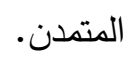

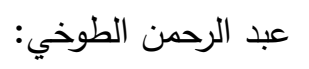

rV - rV

$$
\text { • الأخرى: مقال منشور بموقع الألوكة. }
$$

^r ـ أعلام النساء في عالمي العرب والإسلام: مؤسسة الرسالة

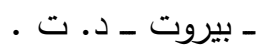

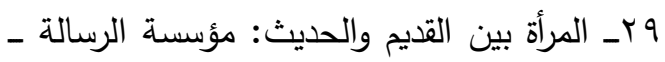

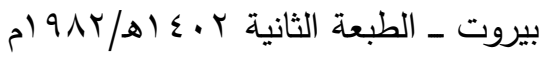

$$
\begin{aligned}
& \text { محمد إسماعيل المقدم: }
\end{aligned}
$$

و ؟ـ عودة الحجاب (المرأة بين تكريم الاسلام وإهانة الجاهلية): دار طيبة - الرياض - السعودية - الطبعة العاشرة

$$
\text { • }
$$

$$
\text { مصطفى السباعي: }
$$

• بـ المرأة بين الفقه والقانون: دار السلام ـ القاهرة ـ الطبعة

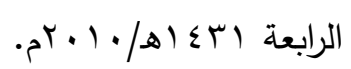

ابن عساكر، أبو القاسم علي بن الحسن (ت :(sov)

1اـ تاريخ دمشق: تحقيق/ عمرو بن غرامة العمروي -

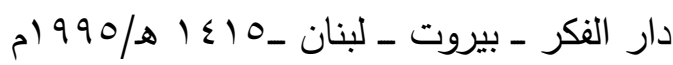

الفسوي، يعقوب بن سفيان بن جوان الفارسي (ت

: A RVV

9 اــ المعرفة والتاريخ: تحقيق/ أكرم ضياء العمري مؤسسة الرسالة - بيروت - ل الطبعة الثانية م) $911 / 81 \leq \cdot 1$

ابن ماجة، أبو عبد الله محمد بن يزيد القزويني (ت اتهار) : מ TR

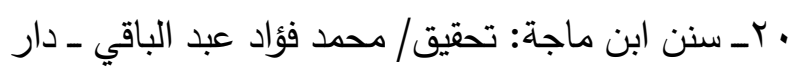
إحياء الكتب العربية ـ فيصل عيسى البابي الحلبي ـ د.

مجد الدين ابن الأثير، أبو السعادات المبارك بن

$$
\text { محمد بن (ت 7 . 7هـ): }
$$

ا آـ النهاية في غريب الحديث والأثر تحقيق: طاهر أحمد الزاوى، محمود محمد الطناحي ـ المكتبة العلمية ـ بيروت . مسلم بن الحجاج أبو الحسن القشيري النيسابوري

$$
\text { : (ت (T) }
$$

r Y _ المسند الصحيح المختصر بنقل العدل عن العدل إلى رسول الله صلى الله عليه وسلم أو صحيح مسلم: تحقيق/ محمد فؤاد عبد الباقي ـ دار إحياء التراث العربي

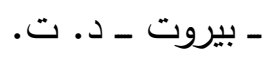

النسائي، أبو عبد الرحمن أحمد بن شعيب بن علي

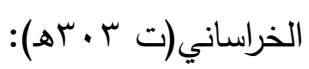




\title{
Good interactions between spouses are bright examples of history from the era of the Prophet until the Abbasid era
}

\author{
DR Yousef Abdulhamid Bennaji. \\ Assistant Professor in Islamic history at \\ The Public Authority For Applied Education \& Training. \\ Kuwait. Ardiya Area, Block 1, Mohammed Ibn Al Qassem Street \\ In front of Jaber Stadium
}

\begin{abstract}
Islamic state and their wives from the time of the Prophet until the Abbasid era, And examples of history have been mentioned for each of the Islamic eras, including examples of the Prophet and his wife Aisha, may God please her, Othman bin Affan, may God please him, and his wife Naela, Omar bin Alaziz and his wife Fatima bint Abdul Malik, And some selected models from the Abbasid era, such as the first Abbasid caliph, Abu al-Abbas, nicknamed the Thug, and his wife Umm Salamah, the daughter of Yaqoub bin Salamah. And Abu Jaafar Al-Mansour and his wife Arwa Al-Qayrawaniyah, And the Caliph Al-Mahdi and his wife Al Khayzran the daughter of AlAtaa, Through these examples, I spoke about the treatment between them in terms of love for women and good manners with them, compassion for women, sacrifice and loyalty, Affordable living, counseling, and my methodology in this research was the descriptive and analytical method based on mentioning examples of good treatment between spouses, Especially those who led the Islamic nation from the era of prophethood until the Abbasid era And that is through what was mentioned in some sources and references, analyzing and commenting on them as much as possible, And I have extracted from this research some results, including: The treatment of spouses during the era of prophethood and the rightly guided caliphate was based on good manners, love, compassion, sacrifice, loyalty and other good qualities without interfering in political matters, Which had the greatest impact of spreading love and intimacy among members of the same family, but among members of society as a whole, The Prophet (may God bless him and grant him peace) gave us the most wonderful examples in his good treatment of wives, He is the best example to emulate, in his deeds, words, and morals, and all the behavioral particles in life. There is no shortage of eras from the existence of a sect of the nation of Muhammad (may God's prayers and peace be upon him) that can be a good example.

This sect or it increased, the treatment between the caliphs and their wives in the Abbasid era turned into a love for women, which made women control the affairs of the state, which caused many calamities for the Abbasid caliphate but for the Islamic World, And making the relationship within the family of the caliphate based on hatred, ambush, and the entrenchment of intrigues and conspiracies instead of love, intimacy and affection that spread in the era of prophethood and the rightly guided caliphate.
\end{abstract}

